4

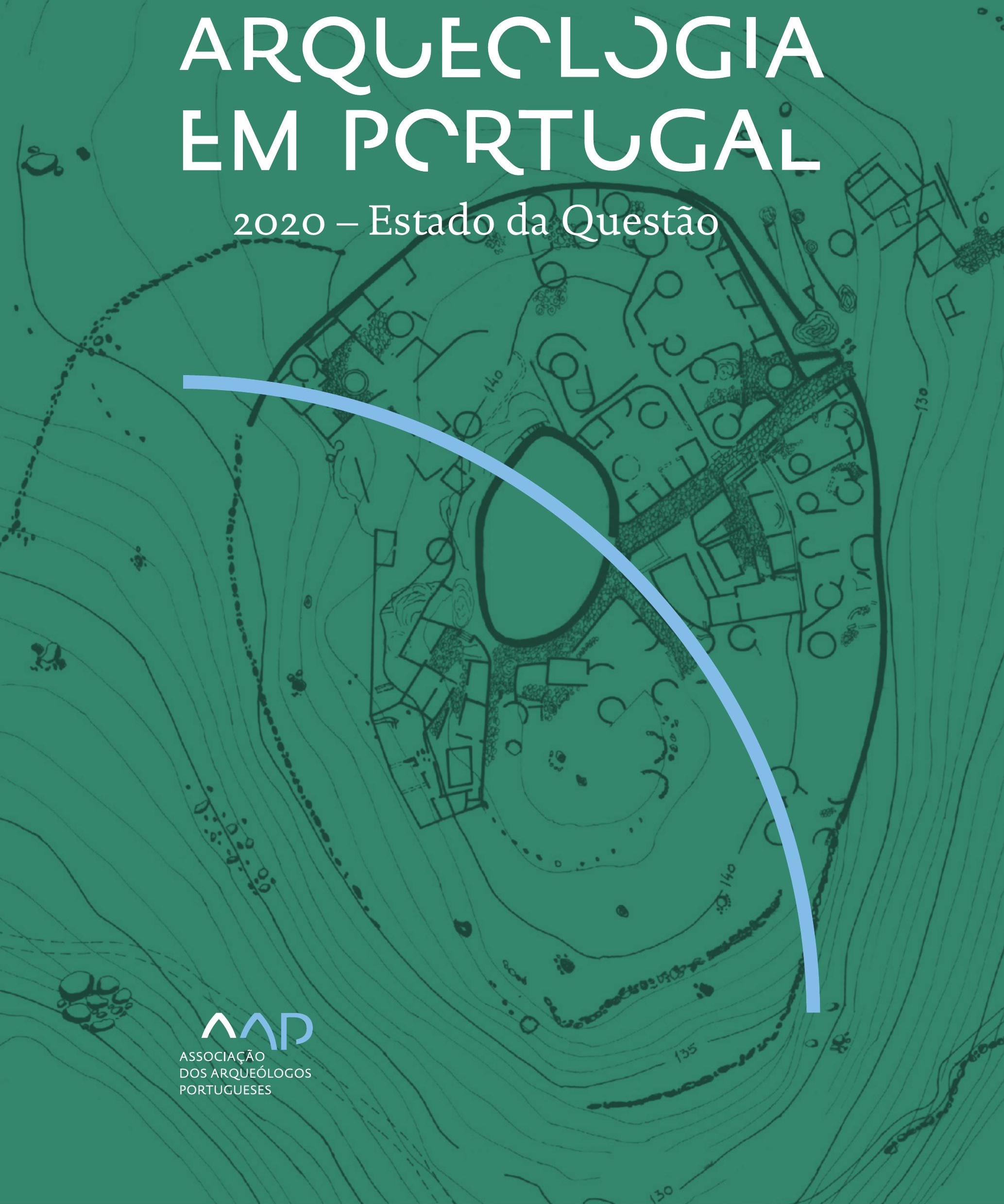


Coordenação editorial: José Morais Arnaud, César Neves e Andrea Martins Design gráfico: Flatland Design

AAP - ISBN: 978-972-9451-89-8

CITCEM - ISBN: 978-989-8970-25-1

Associação dos Arqueólogos Portugueses e CITCEM

Lisboa, 2020

O conteúdo dos artigos é da inteira responsabilidade dos autores. Sendo assim a Associação dos Arqueólogos Portugueses declina qualquer responsabilidade por eventuais equívocos ou questões de ordem ética e legal.

Desenho de capa:

Planta do castro de Monte Mozinho (Museu Municipal de Penafiel).

\section{$\hat{\wedge} \mathrm{P}$}

DOS ARQUEÓLOGOS PORTUGUESES

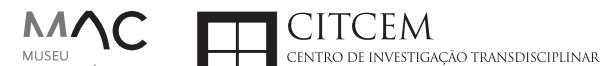
MUSEU
ARQUELLÓGICO
DO CARMO
U.PORTO

FLUP FACULDADE DE LETRAS
UNIVERSIDADE DO PORTO

Apoio

EC para a Ciência 


\section{Índice}

15 Prefácio

José Morais Arnaud

\section{Historiografia e Teoria}

17 Território, comunidade, memória e emoção: a contribuição da história da arqueologia (algumas primeiras e breves reflexões)

Ana Cristina Martins

25 Como descolonizar a arqueologia portuguesa?

Rui Gomes Coelho

41 Arqueologia e Modernidade: uma revisitação pessoal e breve de alguns aspetos da obra homónima de Julian Thomas de 2004

Vítor Oliveira Jorge

57 Dados para a História das Mulheres na Arqueologia portuguesa, dos finais do século XIX aos inícios do século XX: números, nomes e tabelas

Filipa Dimas / Mariana Diniz

73 Retractos da arqueologia portuguesa na imprensa: (in)visibilidades no feminino

Catarina Costeira / Elsa Luís

85 Arqueologia e Arqueólogos no Norte de Portugal Jacinta Bugalhão

101 Vieira Guimarães (1864-1939) e a arqueologia em Tomar: uma abordagem sobre o território e as gentes

João Amendoeira Peixoto / Ana Cristina Martins

115 Os memoráveis? A arqueologia algarvia na imprensa nacional e regional na presente centúria (2001-2019): características, visões do(s) passado(s) e a arqueologia

enquanto marca

Frederico Agosto / João Silva

129 A Evolução da Arqueologia Urbana e a Valorização Patrimonial no Barlavento Algarvio: Os casos de Portimão e Silves

Artur Mateus / Diogo Varandas / Rafael Boavida

\section{Gestão, Valorização e Salvaguarda do Património}

145 O Caderno Reivindicativo e as condições de trabalho em Arqueologia Miguel Rocha / Liliana Matias Carvalho / Regis Barbosa / Mauro Correia / Sara Simões / Jacinta Bugalhão / Sara Brito / Liliana Veríssimo Carvalho / Richard Peace / Pedro Peça / Cézer Santos

155 Os Estudos de Impacte Patrimonial como elemento para uma estratégia sustentável de minimização de impactes no âmbito de reconversões agrícolas Tiago do Pereiro

165 Salvaguarda de Património arqueológico em operações florestais: gestão e sensibilização Filipa Bragança / Gertrudes Zambujo / Sandra Lourenço / Belém Paiva / Carlos Banha / Frederico Tatá Regala / Helena Moura / Jacinta Bugalhão / João Marques / José Correia / Pedro Faria / Samuel Melro

179 Os valores do Património: uma investigação sobre os Sítios Pré-históricos de Arte Rupestre do Vale do Rio Côa e de Siega Verde José Paulo Francisco 
189 Conjugando recursos arqueológicos e naturais para potenciar as visitas ao Geoparque Litoral de Viana do Castelo (Noroeste de Portugal)

Hugo A. Sampaio / Ana M.S. Bettencourt / Susana Marinho / Ricardo Carvalhido

203 Áreas de Potencial Arqueológico na Região do Médio Tejo: Modelo Espacial Preditivo Rita Ferreira Anastácio / Ana Filipa Martins / Luiz Oosterbeek

223 Património Arqueológico e Gestão Territorial: O contributo da Arqueologia para a revisão do PDM de Avis

Ana Cristina Ribeiro

237 A coleção arqueológica do extinto Museu Municipal do Porto - Origens, Percursos e Estudos

Sónia Couto

251 Valpaços - uma nova carta arqueológica

Pedro Pereira / Maria de Fátima Casares Machado

263 Arqueologia na Cidade de Peniche

Adriano Constantino / Luís Rendeiro

273 Arqueologia Urbana: a cidade de Lagos como caso de Estudo Cátia Neto

285 Estratégias de promoção do património cultural subaquático nos Açores. O caso da ilha do Faial

José Luís Neto / José Bettencourt / Luís Borges / Pedro Parreira

297 Carta Arqueológica da Cidade Velha: Uma primeira abordagem

Jaylson Monteiro / Nireide Tavares / Sara da Veiga / Claudino Ramos / Edson Brito /

Carlos Carvalho / Francisco Moreira / Adalberto Tavares

311 Antropologia Virtual: novas metodologias para a análise morfológica e funcional Ricardo Miguel Godinho / Célia Gonçalves

\section{Didáctica da Arqueologia}

327 Como os projetos de Arqueologia podem contribuir para uma comunidade culturalmente mais consciente Alexandra Figueiredo / Claúdio Monteiro / Adolfo Silveira / Ricardo Lopes

337 Educação Patrimonial - Um cidadão esclarecido é um cidadão ativo! Ana Paula Almeida

351 A aproximação da Arqueologia à sala de aula: um caso de estudo no $3^{\circ}$ ciclo do Ensino Básico Luís Serrão Gil

363 Arqueologia 3.o - Pensar e comunicar a Arqueologia para um futuro sustentável Mónica Rolo

377 “Conversa de Arqueólogos" - Divulgar a Arqueologia em tempos de Pandemia Diogo Teixeira Dias

389 Escola Profissional de Arqueologia: desafios e oportunidades Susana Nunes / Dulcineia Pinto / Júlia Silva / Ana Mascarenhas

399 Os Museus de Arqueologia e os Jovens: a oferta educativa para o público adolescente Beatriz Correia Barata / Leonor Medeiros

411 O museu universitário como mediador entre a ciência e a sociedade: o exemplo da secção de arqueologia no Museu de História Natural e da Ciência da Universidade do Porto (MHNC-UP)

Rita Gaspar 
421 Museu de Lanifícios: Real Fábrica de Panos. Atividades no âmbito da Arqueologia Beatriz Correia Barata / Rita Salvado

427 Arqueologia Pública e o caso da localidade da Mata (Torres Novas) Cláudia Manso / Ana Rita Ferreira / Cristiana Ferreira / Vanessa Cardoso Antunes

431 Do sítio arqueológico ao museu: um percurso (também) didático Lídia Fernandes

447 Estão todos convidados para a Festa! E para dançar também... O projecto do Serviço Educativo do Museu Arqueológico do Carmo na $5^{\underline{a}}$ Edição da Festa da Arqueologia Rita Pires dos Santos

459 O “Clã de Carenque”, um projeto didático de arqueologia Eduardo Gonzalez Rocha

469 Mediação cultural: peixe que puxa carroça nas Ruínas Romanas de Troia Inês Vaz Pinto / Ana Patrícia Magalhães / Patrícia Brum / Filipa Santos

481 Didática Arqueológica, experiências do Projeto Mértola Vila Museu Maria de Fátima Palma / Clara Rodrigues / Susana Gómez / Lígia Rafael

\section{Arte Rupestre}

497 Os inventários de arte rupestre em Portugal Mila Simões de Abreu

513 O projeto FIRST-ART - conservação, documentação e gestão das primeiras manifestações de arte rupestre no Sudoeste da Península Ibérica: as grutas do Escoural e Maltravieso Sara Garcês / Hipólito Collado / José Julio García Arranz / Luiz Oosterbeek / António Carlos Silva / Pierluigi Rosina / Hugo Gomes / Anabela Borralheiro Pereira / George Nash / Esmeralda Gomes / Nelson Almeida / Carlos Carpetudo

523 Trabalhos de documentação de arte paleolítica realizados no âmbito do projeto PalæoCôa André Tomás Santos / António Fernando Barbosa / Luís Luís / Marcelo Silvestre / Thierry Aubry

537 Imagens fantasmagóricas, silhuetas elusivas: as figuras humanas na arte do Paleolítico Superior da região do Côa Mário Reis

$55^{1}$ Os motivos zoomórficos representados nas placas de tear de Vila Nova de São Pedro (Azambuja, Portugal) Andrea Martins / César Neves / José M. Arnaud / Mariana Diniz

571 Arte Rupestre do Monte de Góios (Lanhelas, Caminha). Síntese dos resultados dos trabalhos efectuados em 2007-2009 Mário Varela Gomes

599 Gravuras rupestres de barquiformes no Monte de S. Romão, Guimarães, Noroeste de Portugal Daniela Cardoso

613 Círculos segmentados gravados na Bacia do Rio Lima (Noroeste de Portugal): contributos para o seu estudo Diogo Marinho / Ana M.S. Bettencourt / Hugo Aluai Sampaio

631 Equídeos gravados no curso inferior do Rio Mouro, Monção (NW Portugal). Análise preliminar Coutinho, L.M. / Bettencourt, A.M.S / Sampaio, Hugo A.S

645 Paletas na Arte Rupestre do Noroeste de Portugal. Inventário preliminar Bruna Sousa Afonso / Ana M. S. Bettencourt / Hugo A. Sampaio 


\section{Pré-História}

661 O projeto Miño/Minho: balanço de quatro anos de trabalhos arqueológicos Sérgio Monteiro-Rodrigues / João Pedro Cunha-Ribeiro / Eduardo Méndez-Quintas / Carlos Ferreira / Pedro Xavier / José Meireles / Alberto Gomes / Manuel Santonja / Alfredo Pérez-González

677 A ocupação paleolítica da margem esquerda do Baixo Minho: a indústria lítica do sítio de Pedreiras 2 (Monção, Portugal) e a sua integração no contexto regional Carlos Ferreira / João Pedro Cunha-Ribeiro / Sérgio Monteiro-Rodrigues / Eduardo Méndez-Quintas / Pedro Xavier / José Meireles / Alberto Gomes / Manuel Santonja / Alfredo Pérez-González

693 O sítio acheulense do Plistocénico médio da Gruta da Aroeira Joan Daura / Montserrat Sanz / Filipa Rodrigues / Pedro Souto / João Zilhão

703 As sociedades neandertais no Barlavento algarvio: modelos preditivos com recurso aos SIG

Daniela Maio

715 A utilização de quartzo durante o Paleolítico Superior no território dos vales dos rios Vouga e Côa

Cristina Gameiro / Thierry Aubry / Bárbara Costa / Sérgio Gomes / Luís Luís / Carmen Manzano / André Tomás Santos

733 Uma perspetiva diacrónica da ocupação do concheiro do Cabeço da Amoreira (Muge, Portugal) a partir da tecnologia lítica Joana Belmiro / João Cascalheira / Célia Gonçalves

745 Novos dados sobre a Pré-história Antiga no concelho de Palmela. A intervenção arqueológica no sítio do Poceirão I

Michelle Teixeira Santos

757 Problemas em torno de Datas Absolutas Pré-Históricas no Norte do Alentejo Jorge de Oliveira

771 Povoamento pré-histórico nas áreas montanhosas do NO de Portugal: o Abrigo 1 de Vale de Cerdeira Pedro Xavier / José Meireles / Carlos Alves

783 Apreciação do povoamento do Neolítico Inicial na Baixa Bacia do Douro. A Lavra I (Serra da Aboboreira) como caso de estudo Maria de Jesus Sanches

797 O Processo de Neolitização na Plataforma do Mondego: os dados do Sector C do Outeiro dos Castelos de Beijós (Carregal do Sal)

João Carlos de Senna-Martinez / José Manuel Quintã Ventura / Andreia Carvalho / Cíntia Maurício

823 Novos trabalhos na Lapa da Bugalheira (Almonda, Torres Novas) Filipa Rodrigues / Pedro Souto / Artur Ferreira / Alexandre Varanda / Luís Gomes / Helena Gomes / João Zilhão

837 A pedra polida e afeiçoada do sítio do Neolítico médio da Moita do Ourives (Benavente, Portugal)

César Neves

857 Casal do Outeiro (Encarnação, Mafra): novos contributos para o conhecimento do povoamento do Neolítico final na Península de Lisboa.

Cátia Delicado / Carlos Maneira e Costa / Marta Miranda / Ana Catarina Sousa

873 Stresse infantil, morbilidade e mortalidade no sítio arqueológico do Neolítico Final/ Calcolítico ( $4^{\circ}$ e $3^{\circ}$ milénio a.C.) do Monte do Carrascal 2 (Ferreira do Alentejo, Beja) Liliana Matias de Carvalho / Sofia N. Wasterlain 
885 Come together: O Conjunto Megalítico das Motas (Monção, Viana do Castelo) e as expressões Campaniformes do Alto Minho Ana Catarina Basílio / Rui Ramos

899 Trabalhos arqueológicos no sítio Calcolítico da Pedreira do Poio Carla Magalhães / João Muralha / Mário Reis / António Batarda Fernandes

913 O sítio arqueológico de Castanheiro do Vento. Da arquitectura do sítio à arquitectura de um território João Muralha Cardoso

925 Estudo zooarqueológico das faunas do Calcolítico final de Vila Nova de São Pedro (Azambuja, Portugal): Campanhas de 2017 e 2018 Cleia Detry / Ana Catarina Francisco / Mariana Diniz / Andrea Martins / César Neves / José Morais Arnaud

943 As faunas depositadas no Museu Arqueológico do Carmo provenientes de Vila Nova de São Pedro (Azambuja): as campanhas de 1937 a 1967 Ana Catarina Francisco / Cleia Detry / César Neves / Andrea Martins / Mariana Diniz / José Morais Arnaud

959 Análise funcional de material lítico em sílex do castro de Vila Nova de S. Pedro (Azambuja, Portugal): uma primeira abordagem Rafael Lima

971 O recinto da Folha do Ouro 1 (Serpa) no contexto dos recintos de fossos calcolíticos alentejanos

António Carlos Valera / Tiago do Pereiro / Pedro Valério / António M. Monge Soares

\section{Proto-História}

987 Produção de sal marinho na Idade do Bronze do noroeste Português. Alguns dados para uma reflexão

Ana M. S. Bettencourt / Sara Luz / Nuno Oliveira / Pedro P. Simões / Maria Isabel C. Alves / Emílio Abad-Vidal

1001 A estátua-menir do Pedrão ou de São Bartolomeu do Mar (Esposende, noroeste de Portugal) no contexto arqueológico da fachada costeira de entre os rios Neiva e Cávado Ana M. S. Bettencourt / Manuel Santos-Estévez / Pedro Pimenta Simões / Luís Gonçalves

1015 O Castro do Muro (Vandoma/Baltar, Paredes) - notas para uma biografia de ocupação da Idade do Bronze à Idade Média

Maria Antónia D. Silva / Ana M. S. Bettencourt / António Manuel S. P. Silva / Natália Félix

1031 Do Bronze Final à Idade Média - continuidades e hiatos na ocupação de Povoados em Oliveira de Azeméis João Tiago Tavares / Adriaan de Man

1041 As faunas do final da Idade do Bronze no Sul de Portugal: leituras desde o Outeiro do Circo (Beja)

Nelson J. Almeida / Íris Dias / Cleia Detry / Eduardo Porfírio / Miguel Serra

1055 A Espada do Monte das Oliveiras (Serpa) - uma arma do Bronze Pleno do Sudoeste Rui M. G. Monge Soares / Pedro Valério / Mariana Nabais / António M. Monge Soares

1065 São Julião da Branca (Albergaria-a-Velha) - Investigação e valorização de um povoado do Bronze Final

António Manuel S. P. Silva / Paulo A. P. Lemos / Sara Almeida e Silva / Edite Martins de Sá

1083 Do castro de S. João ao Mosteiro de Santa Clara: notícia de uma intervenção arqueológica, em Vila do Conde Rui Pinheiro 
1095 O castro de Ovil (Espinho), um quarto de século de investigação - resultados e questões em aberto

Jorge Fernando Salvador / António Manuel S. P. Silva

1111 O Castro de Salreu (Estarreja), um povoado proto-histórico no litoral do Entre Douro e Vouga

Sara Almeida e Silva / António Manuel S. P. Silva / Paulo A. P. Lemos / Edite Martins de Sá

1127 Castro de Nossa Senhora das Necessidades (Sernancelhe): uma primeira análise artefactual Telma Susana O. Ribeiro

${ }_{1141}$ A cividade de Bagunte. O estado atual da investigação Pedro Brochado de Almeida

1153 Zoomorfos na cerâmica da Idade do Ferro no NW Peninsular: inventário, cronologias e significado Nuno Oliveira / Cristina Seoane

1163 Vasos gregos em Portugal: diferentes maneiras de contar a história do intercâmbio cultural na Idade do Ferro

Daniela Ferreira

1175 Os exotica da necrópole da Idade do Ferro do Olival do Senhor dos Mártires (Alcácer do Sal) no seu contexto regional

Francisco B. Gomes

\section{Antiguidade Clássica e Tardia}

1191 O uso de madeira como combustível no sítio da Quinta de Crestelos (Baixo Sabor): da Idade do Ferro à Romanização Filipe Vaz / João Tereso / Sérgio Simões Pereira / José Sastre / Javier Larrazabal Galarza / Susana Cosme / José António Pereira / Israel Espi

1207 Cultivos de Época Romana no Baixo Sabor: continuidade em tempos de mudança? João Pedro Tereso / Sérgio Simões Pereira / Filipe Santos / Luís Seabra / Filipe Vaz

1221 A casa romana na Hispânia: aplicação dos modelos itálicos nas províncias ibéricas Fernanda Magalhães / Diego Machado / Manuela Martins

1235 As pinturas murais romanas da Rua General Sousa Machado, n. ${ }^{5}$ 1, Chaves José Carvalho

1243 Trás do Castelo (Vale de Mir, Pegarinhos, Alijó) - Uma exploração agrícola romana do Douro

Tony Silvino / Pedro Pereira

1255 A sequência de ocupação no quadrante sudeste de Bracara Augusta: as transformações de uma unidade doméstica Lara Fernandes / Manuela Martins

1263 Os Mosaicos com decoração geométrica e geométrico-vegetalista dos sítios arqueológicos da área do Conuentus Bracaraugustanus. Novas abordagens quanto à conservação, restauro, decoração e datação Maria de Fátima Abraços / Licínia Wrench

1277 “Casa Romana” do Castro de São Domingos (Cristelos, Lousada): Escavação, Estudo e Musealização Paulo André de P. Lemos

1291 A arqueobotânica no Castro de Guifões (Matosinhos, Noroeste de Portugal): O primeiro estudo carpológico

Luís Seabra / Andreia Arezes / Catarina Magalhães / José Varela / João Pedro Tereso 
1305 Um Horreum Augustano na Foz do Douro (Monte do Castelo de Gaia, Vila Nova de Gaia) Rui Ramos

1311 Ponderais romanos na Lusitânia: padrões, formas, materiais e contextos de utilização Diego Barrios Rodríguez

1323 Um almofariz centro-itálico na foz do Mondego

Marco Penajoia

1335 Estruturas romanas de Carnide - Lisboa Luísa Batalha / Mário Monteiro / Guilherme Cardoso

1347 O contexto funerário do sector da "necrópole NO" da Rua das Portas de S. Antão (Lisboa): o espaço, os artefactos, os indivíduos e a sua interconectividade na interpretação do passado Sílvia Loja, José Carlos Quaresma, Nelson Cabaço, Marina Lourenço, Sílvia Casimiro, Rodrigo Banha da Silva, Francisca Alves-Cardoso

${ }_{1361}$ Povoamento em época Romana na Amadora - resultados de um projeto pluridisciplinar Gisela Encarnação / Vanessa Dias

1371 A Arquitectura Residencial em Mirobriga (Santiago do Cacém): contributo a partir de um estudo de caso Filipe Sousa / Catarina Felício

${ }_{1385}$ O fim do ciclo. Saneamento e gestão de resíduos nos edifícios termais de Mirobriga (Santiago do Cacém)

Catarina Felício / Filipe Sousa

1399 Balsa, Topografia e Urbanismo de uma Cidade Portuária Vítor Silva Dias / João Pedro Bernardes / Celso Candeias / Cristina Tété Garcia

1413 No Largo das Mouras Velhas em Faro (2017): novas evidências da necrópole norte de Ossonoba e da sua ocupação medieval Ricardo Costeira da Silva / Paulo Botelho / Fernando Santos / Liliana Nunes

1429 Instrumentos de pesca recuperados numa fábrica de salga em Ossonoba (Faro) Inês Rasteiro / Ricardo Costeira da Silva / Paulo Botelho

1439 A Necrópole Romana do Eirô, Duas Igrejas (Penafiel): intervenção arqueológica de 2016 Laura Sousa / Teresa Soeiro

1457 Ritual, descarte ou afetividade? A presença de Canis lupus familiaris na Necrópole Noroeste de Olisipo (Lisboa)

Beatriz Calapez Santos / Sofia Simões Pereira / Rodrigo Banha da Silva / Sílvia Casimiro / Cleia Detry / Francisca Alves Cardoso

1467 Dinâmicas económicas em Bracara na Antiguidade Tardia Diego Machado / Manuela Martins / Fernanda Magalhães / Natália Botica

1479 Cerâmicas e Vidros da Antiguidade Tardia do Edifício sob a Igreja do Bom Jesus (Vila Nova de Gaia) Joaquim Filipe Ramos

1493 Novos contributos para a topografia histórica de Mértola no período romano e na Antiguidade Tardia Virgílio Lopes

\section{8. Época Medieval}

1511 Cerâmicas islâmicas no Garb setentrional "português": algumas evidências e incógnitas Constança dos Santos / Helena Catarino / Susana Gómez / Maria José Gonçalves / Isabel Inácio / Gonçalo Lopes / Jacinta Bugalhão / Sandra Cavaco / Jaquelina Covaneiro / Isabel Cristina Fernandes / Ana Sofia Gomes 
1525 Contributo para o conhecimento da cosmética islâmica, em Silves, durante a Idade Média Rosa Varela Gomes

1537 Yábura e o seu território - uma análise histórico-arqueológica de Évora entre os séculos VIII-XII José Rui Santos

1547 A encosta sul do Castelo de Palmela - resultados preliminares da escavação arqueológica Luís Filipe Pereira / Michelle Teixeira Santos

1559 A igreja de São Lourenço (Mouraria, Lisboa): um conjunto de silos e de cerâmica medieval islâmica

Andreia Filipa Moreira Rodrigues

1571 O registo material de movimentações populacionais no Médio Tejo, durante os séculos XII-XIII. Dois casos de "sunken featured buildings", nos concelhos de Cartaxo e Torres Novas Marco Liberato / Helena Santos / Nuno Santos

1585 O nordeste transmontano nos alvores da Idade média. Notas para reflexão Ana Maria da Costa Oliveira

1601 Sepulturas escavadas na rocha do Norte de Portugal e do Vale do Douro: primeiros resultados do Projecto SER-NPVD

Mário Jorge Barroca / César Guedes / Andreia Arezes / Ana Maria Oliveira

1619 "Portucalem Castrum Novum" entre o Mediterrâneo e o Atlântico: o estudo dos materiais cerâmicos alto-medievais do arqueossítio da rua de D. Hugo, nํ. 5 (Porto) João Luís Veloso

1627 A Alta Idade Média na fronteira de Lafões: notas preliminares sobre a Arqueologia no Concelho de Vouzela

Manuel Luís Real / Catarina Tente

1641 Um conjunto cerâmico medieval fora de portas: um breve testemunho aveirense Susana Temudo

${ }_{1651}$ Os Lóios do Porto: uma perspetiva integrada no panorama funerário da Baixa Idade Média à Época Moderna em meios urbanos em Portugal

Ana Lema Seabra

1659 O Caminho Português Interior de Santiago como eixo viário na Idade Média Pedro Azevedo

1665 Morfologia Urbana: Um exercício em torno do Castelo de Ourém André Donas-Botto / Jaqueline Pereira

1677 Intervenção arqueológica na Rua Marquês de Pombal/Largo do Espírito Santo (Bucelas, Loures)

Florbela Estêvão / Nathalie Antunes-Ferreira / Dário Ramos Neves / Inês Lisboa

1691 O Cemitério Medieval do Poço do Borratém e a espacialidade funerária na cidade de Lisboa Inês Belém / Vanessa Filipe / Vasco Noronha Vieira / Sónia Ferro / Rodrigo Banha da Silva

1705 Um Espaço Funerário Conventual do séc. XV em Lisboa: o caso do Convento de São Domingos da Cidade Sérgio Pedroso / Sílvia Casimiro / Rodrigo Banha da Silva / Francisca Alves Cardoso

\section{9. Época Moderna e Contemporânea}

1721 Arqueologia Moderna em Portugal: algumas reflexões críticas em torno da quantificação de conjuntos cerâmicos e suas inferências históricas e antropológicas Rodrigo Banha da Silva / André Bargão / Sara da Cruz Ferreira

1733 Faianças de dois contextos entre os finais do século XVI e XVIII do Palácio dos Condes de Penafiel, Lisboa

Martim Lopes / Tomás Mesquita 
1747 Um perfil de consumo do século XVIII na foz do Tejo: O caso do Mercado da Ribeira, Lisboa Sara da Cruz Ferreira / Rodrigo Banha da Silva / André Bargão

1761 Os Cachimbos dos Séculos XVII e XVIII do Palácio Mesquitela e Convento dos Inglesinhos (Lisboa)

Inês Simão / Marina Pinto / João Pimenta / Sara da Cruz Ferreira / André Bargão / Rodrigo Banha da Silva

1775 "Tomar os fumos da erua que chamão em Portugal erua sancta». Estudo de Cachimbos provenientes da Rua do Terreiro do Trigo, Lisboa

Miguel Martins de Sousa / José Pedro Henriques / Vanessa Galiza Filipe

1787 Cachimbos de Barro Caulínitico da Sé da Cidade Velha (República de Cabo Verde)

Rodrigo Banha da Silva / João Pimenta / Clementino Amaro

1801 Algumas considerações sobre espólio não cerâmico recuperado no Largo de Jesus (Lisboa) Carlos Boavida

1815 Adereços de vidro, dos séculos XVI-XVIII, procedentes do antigo Convento de Santana de Lisboa (anéis, braceletes e contas)

Joana Gonçalves / Rosa Varela Gomes / Mário Varela Gomes

1837 Da ostentação, luxo e poder à simplicidade do uso quotidiano: arqueologia e simbologia de joias e adornos da Idade Moderna Portuguesa Jéssica Iglésias

1849 Os amuletos em Portugal - dos objetos às superstições: o coral vermelho Alexandra Vieira

1865 Cerâmicas de Vila Franca de Xira nos séculos XV e XVI Eva Pires

1879 «Não passa por teu o que me pertence». Marcas de individualização associadas a faianças do Convento de Nossa Senhora de Aracoeli, Alcácer do Sal Catarina Parreira / Íris Fragoso / Miguel Martins de Sousa

1891 Cerâmica de Leiria: alguns focos de produção

Jaqueline Pereira / André Donas-Botto

1901 Os Fornos na Rua da Biquinha, em Óbidos Hugo Silva / Filipe Oliveira

1909 A casa de Pêro Fernandes, contador dos contos de D. Manuel I: o sítio arqueológico da Silha do Alferes, Seixal (século XVI) Mariana Nunes Ferreira

1921 O Alto da Vigia (Sintra) e a vigilância e defesa da costa Alexandre Gonçalves / Sandra Santos

1937 O contexto da torre sineira da Igreja de Santa Maria de Loures Paulo Calaveira / Martim Lopes

1949 A Necrópole do Hospital Militar do Castelo de São Jorge e as práticas funerárias na Lisboa de Época Moderna Susana Henriques / Liliana Matias de Carvalho / Ana Amarante / Sofia N. Wasterlain

1963 SAND - Sarilhos Grandes Entre dois Mundos: o adro da Igreja e a Paleobiologia dos ossos humanos recuperados

Paula Alves Pereira / Roger Lee Jesus / Bruno M. Magalhães

1975 Expansão urbana da vila de Cascais no século XVII e XVIII: a intervenção arqueológica na Rua da Vitória no 15 a 17

Tiago Pereira / Vanessa Filipe

1987 Novos dados para o conhecimento do Urbanismo de Faro em época Moderna Ana Rosa 
1995 Um exemplo de Arqueologia Urbana em Alcoutim: o Antigo Edifício dos CTT Marco Fernandes / Marta Dias / Alexandra Gradim / Virgílio Lopes / Susana Gómez Martínez

2007 Palácio dos Ferrazes (Rua das Flores/Rua da Vitória, Porto): a cocheira de Domingos Oliveira Maia

Francisco Raimundo

2021 As muitas vidas de um edifício urbano: História, Arqueologia e Antropologia no antigo Recreatório Paroquial de Penafiel Helena Bernardo / Jorge Sampaio / Marta Borges

2035 O convento de Nossa Senhora da Esperança de Ponta Delgada: o contributo da arqueologia para o conhecimento de um monumento identitário João Gonçalves Araújo / N’Zinga Oliveira

2047 Arqueologia na ilha do Corvo... em busca da capela de Nossa Senhora do Rosário Tânia Manuel Casimiro / José Luís Neto / Luís Borges / Pedro Parreira

2059 Perdidos à vista da Costa. Trabalhos arqueológicos subaquáticos na Barra do Tejo Jorge Freire / José Bettencourt / Augusto Salgado

2071 Arqueologia marítima em Cabo Verde: enquadramento e primeiros resultados do projecto CONCHA

José Bettencourt / Adilson Dias / Carlos Lima / Christelle Chouzenoux / Cristóvão Fonseca / Dúnia Pereira / Gonçalo Lopes / Inês Coelho / Jaylson Monteiro / José Lima / Maria Eugénia Alves / Patrícia Carvalho / Tiago Silva

2085 Trabalhos arqueológicos na Cidade Velha (Ribeira Grande de Santiago, Cabo Verde): reflexões sobre um projecto de investigação e divulgação patrimonial André Teixeira / Jaylson Monteiro / Mariana Mateus / Nireide Tavares / Cristovão Fonseca / Gonçalo C. Lopes / Joana Bento Torres / Dúnia Pereira / André Bargão / Aurélie Mayer / Bruno Zélie / Carlos Lima / Christelle Chouzenoux / Inês Henriques / Inês Pinto Coelho / José Lima / Patrícia Carvalho / Tiago Silva

2103 A antiga fortificação de Quelba / Khor Kalba (E.A.U.). Resultados de quatro campanhas de escavações, problemáticas e perspectivas futuras Rui Carita / Rosa Varela Gomes / Mário Varela Gomes / Kamyar Kamyad

2123 Colónias para homens novos: arqueologia da colonização agrária fascista no noroeste ibérico Xurxo Ayán Vila / José Mạ . Señorán Martín 


\title{
CERÂMICAS ISLÂMICAS NO GARB SETENTRIONAL "PORTUGUÊS": ALGUMAS EVIDÊNCIAS E INCÓGNITAS
}

Constança dos Santos ${ }^{1}$, Helena Catarino ${ }^{2}$, Susana Gómez ${ }^{3}$, Maria José Gonçalves ${ }^{4}$, Isabel Inácio ${ }^{5}$, Gonçalo Lopes ${ }^{6}$, Jacinta Bugalhão $^{7}$, Sandra Cavaco ${ }^{8}$, Jaquelina Covaneiro ${ }^{9}$, Isabel Cristina Fernandes ${ }^{10}$, Ana Sofia Gomes ${ }^{11}$

\begin{abstract}
RESUMO
O presente artigo apresenta uma primeira síntese da presença de cerâmicas islâmicas no território setentrional do Garb “português” partindo da pesquisa bibliográfica, com o objectivo de expor e discutir as presenças / ausências de cerâmicas correlacionáveis com protótipos islâmicos entre os séculos VIII e XII, comparando as realidades conhecidas a norte e a sul do Douro. A partir do seu mapeamento tentar-se-á definir e caracterizar realidades geográficas e de povoamento, com particularidades relativas à sua maior ou menor relação com o mundo islâmico, contribuindo assim para a definição de um limite territorial do Garb al-Andalus a partir dos dados arqueológicos.
\end{abstract}

Palavras-chave: Cerâmica islâmica, Marca Inferior, Distribuição, Fronteira.

ABSTRACT

This paper presents a first synthesis about the presence of Islamic ceramics in the northern territory of the "Portuguese" Garb, based on bibliographic research, with the aim to expose and discuss the material presence / absence of Islamic prototypes between the $8^{\text {th }}$ and $12^{\text {th }}$ centuries, comparing the realities known in the north and south of the Douro River. From its mapping, an attempt will be made to define and characterize geographic and population realities, with particularities related to their greater or lesser relation with the Islamic word, thus contributing to the definition of a territorial limit of Garb al-Andalus from archaeological data.

Keywords: Islamic Ceramics, Lower March, Distribution, Frontier.

\footnotetext{
1. CIGA*; constancavs@gmail.com

2. CIGA* / Universidade de Coimbra; hcatarino@fl.uc.pt

3. CIGA* / Universidade de Évora / Campo Arqueológico de Mértola; susanagomez@sapo.pt

4. CIGA* / Município de Silves; maria.goncalves@cm-silves.pt

5. CIGA* / Direcção-Geral do Património Cultural; isabelminacio@gmail.com

6. CIGA*; g.simoeslopes@gmail.com

7. CIGA* / Direcção-Geral do Património Cultural; jacintabugalhao@gmail.com

8. CIGA* / Câmara Municipal de Tavira; scavaco@cm-tavira.pt

9. CIGA* / Câmara Municipal de Tavira; jaquelinacovaneiro@hotmail.com

10. CIGA* / Museu Municipal de Palmela; isacrisff@gmail.com

11. CIGA* / Direcção-Geral do Património Cultural; agomes@dgpc.pt

* Grupo de Estudo sobre Cerâmica Islâmica do Garb al-Andalus. ciga.portugal@gmail.com. Centro de Estudos em Arqueologia, Artes e Ciências do Património.
} 


\section{INTRODUÇÃO}

Quando pensamos em cerâmica islâmica no Garb setentrional português deparamo-nos com um quase vazio de evidências para um território de enormes dimensões, integrado na Marca Inferior. Procurar essas evidências, nomeadamente na bibliografia, continua a ser uma tarefa difícil. Por um lado, pelas próprias características intrínsecas de um território de fronteira, como espaço de coexistências, onde a presença de comunidades muçulmanas seria diminuta e descontínua; por outro lado, porque quando se estuda a Alta Idade Média é, sobretudo, para realçar a "reconquista" e a importância, a partir do século IX, do repovoamento asturo-leonês, permanecendo um défice de conhecimento sobre o século VIII e a maior parte dos seguintes. Deve salientar-se que a presença de cerâmicas islâmicas não é sinónimo directo de domínio islâmico ou presença de comunidades muçulmanas, sendo múltiplas as explicações possíveis para a presença de cerâmicas oriundas do Sul ou produzidas sob influência cultural do Sul nestes territórios de fronteira.

Com este trabalho pretendemos, assim, apresentar uma síntese das cerâmicas que conseguimos rastrear, eventual ou seguramente correlacionáveis com a cultura material islâmica e, principalmente, reconhecer o muito que há ainda por pesquisar. Se é certo que, no Entre-Minho-e-Douro, a presença de vestígios arqueológicos islâmicos é quase nula, sendo também escassas as referências nas fontes documentais, para o Vale do Douro, a toponímia pode ajudar-nos a colmatar ausências de testemunhos arqueológicos. Ainda assim, mesmo sendo esporádicas e pouco explícitas, as referências bibliográficas aludem a alguns materiais que pretendemos indagar. Para sul do Douro, começa a entender-se melhor a presença de cerâmicas islâmicas que convivem com produções locais/regionais de matriz moçárabe. Contudo, salvo o caso de Coimbra e, pontualmente, de outros casos do Centro português, as evidências materiais publicadas continuam a ser muito desiguais e nem sempre seguramente indexáveis às produções cerâmicas inequivocamente islâmicas ou de influência islâmica.

Partindo do exposto, apresentamos uma primeira aproximação às presenças/ausências de cerâmicas correlacionáveis com protótipos islâmicos entre os séculos VIII e XII, no território em análise, comparando as realidades conhecidas a norte e a sul do Dou- ro. A partir do seu mapeamento tentaremos definir e caracterizar realidades geográficas e de povoamento, com particularidades relativas à presença islâmica.

\section{O GARB SETENTRIONAL OU TAGR-AL-ADNÀ}

O Garb Setentrional ou Tagr-al-Adnà (a Marca Inferior) define-se, essencialmente, pela sua condição de território de fronteira, encerrando todas as vicissitudes e dinâmicas que a circunstância implica. Esta vasta área, que num primeiro momento tinha como limite sul o vale do Tejo e a norte chegava à bacia do Douro, actuou como território limítrofe entre o al-Andalus e o mundo cristão. Podemos entender esta zona de fronteira, que separava os espaços geopolíticos do Sul islâmico dos do Norte cristão, como uma área de limites difusos, encontrando-se marcada pelos avanços e retrocessos dos reinos cristãos do Norte e do poder do Sul islâmico, aliados a um controlo territorial por vezes igualmente difuso. Deste modo, temos um território dinâmico, muito permeável, onde as fronteiras políticas não se encontram bem delimitadas, alterando-se em função dos equilíbrios de forças de cada soberano e dos poderes locais.

A escassez de fontes e de estudos arqueológicos que encontramos para a região em causa, não nos permite um conhecimento consistente da sua organização territorial. No entanto, sabemos que, a norte do Tejo, a conquista islâmica fez-se, maioritariamente, através de pactos de capitulação e as principais cidades entregaram-se sem luta. Deste modo, é lógico pensar que o novo domínio muçulmano, estabelecido a partir da conquista de 711, não pressupôs mudanças bruscas no ordenamento territorial, social e económico desta vasta área de fronteira, mantendo-se as unidades administrativas existentes. As antigas dioceses visigodas correspondem agora, grosso modo, às novas províncias administrativas, onde os centros urbanos, herdeiros da cidade visigótica, exercem um poder central mais ou menos activo. Contudo, mesmo dentro da sua fragilidade, estes serão essenciais como polos organizadores do território, segundo as directrizes emanadas do poder de Córdova, assentando a ocupação desta vasta área de fronteira, maioritariamente, num povoamento de carácter rural, disperso e de fraca intensidade. Organizando-se em grupos de vizinhos: villa / "aldeia" / alcaria e em pequenos casais agrícolas, o mundo rural estrutura-se 
em enclaves fortificados (castrum / hisn e talaiya), que eram vigilantes das "paisagens" que defendiam. Os husun tornam-se centros de novos distritos rurais islâmicos, fixando sobre o terreno o controlo e a delimitação destes. Estas comunidades rurais mantêm-se semi-autónomas relativamente ao poder central, assimilando de forma mais ou menos intensa a cultura islâmica, mas mantendo-se essencialmente cristãs. Há ainda a considerar, igualmente, a presença de muladís e de grupos de berberes. Verificamos, assim, uma pluralidade social e cultural que caracteriza esta extensa área fronteiriça, onde os poderes cristãos e islâmicos nem sempre gozaram de um controlo efectivo, num espaço de coexistências sociais e culturais, plasmadas nas suas materialidades, de caracterização complexa.

\section{TERRITÓRIO E CARTA ARQUEOLÓGICA}

O extenso território que constituía a Marca Inferior, ou Tagr-al-Adnà, como já referimos, estendia-se, num primeiro momento, desde o vale do Tejo até à bacia do Douro, chegando mesmo a alcançar áreas a norte deste rio. Contudo, em meados do século IX, o limite norte vai abandonar a região do Douro localizando-se, agora, no sistema central (Serra da Gata - Malcata -Estrela). A sul, no vale do Tejo, a estrutura política islâmica é mais estável e os dados arqueológicos são mais abundantes e melhor reconhecíveis no terreno. Partindo destas diferenças mais marcantes em termos arqueológicos, uma vez que um tão extenso território contém, necessariamente, inúmeras realidades e diversidades, considerámos os seguintes limites territoriais: a norte a bacia do Douro (em ambas as margens), a leste, e apenas por questões práticas, a actual fronteira com Espanha, e a sul a Serra de Aires e Candeeiros. Considerando a parca informação que encontramos nas fontes escritas, quer cristãs quer muçulmanas, relativamente a este território, torna-se necessário procurar os traços dessa presença noutros marcadores, diferentes das fontes tradicionais. Para tal são essenciais os dados que a arqueologia nos pode fornecer, sendo nestes que o presente estudo se baseia. Contudo, tendo presente as características já referidas destes territórios de fronteira, surgem muitas questões quanto aos indícios materiais da frequência e/ou permanência de grupos muçulmanos e quanto à interpretação de cerâmicas eventualmente originárias de territórios islâmicos ou produzidas sob influência destas. A actividade arqueológica (prospecção e escavação) tem fornecido apenas pontualmente dados relativamente a sítios com vestígios materiais eventualmente correlacionáveis com a ocupação islâmica, ou onde se exumaram cerâmicas que reflectem uma filiação nos contactos culturais e comerciais com o al-Andalus. O presente estudo organiza-se de norte para sul, partindo da bacia do Douro (no seu lado norte) até, como já referido, à Serra de Aires e Candeeiros, a sul, tendo como base a análise exaustiva da bibliografia arqueológica.

\subsection{Território a norte do Douro}

Relativamente ao território a norte do Douro, é notória a escassez de vestígios relacionáveis com a presença islâmica, que não chegou a ser efectiva, embora se encontrem evidentes marcas na toponímia da região e as fontes refiram o estabelecimento de grupos berberes Masmuda na zona do Porto e em Trás-os-Montes (Figura 1 e Figura 2).

Neste contexto, na última fase de ocupação da Quinta do Paço Velho (Ponte de Lima, Viana do Castelo), dos séculos VII/VIII, foi identificada cerâmica cujas características as integram entre exemplares islâmicos de época emiral (Brochado, 2004, fig. 42, 끌), nomeadamente púcaros de bordo direito arredondado e colo recto ou levemente curvo, e um jarro de colo alto, com moldura em carena a meio deste, encontrando-se exemplares idênticos em contextos meridionais, como Mérida, Cáceres e Málaga.

$\mathrm{Na}$ margem direita do rio Sabor, no Cemitério dos Mouros (Cilhades, Felgar, Torre de Moncorvo), foi identificado um importante conjunto de materiais cerâmicos datáveis entre os séculos VIII e XI, que indicia marcado cariz islâmico emiral/califal, convivendo com outros materiais que podemos adscrever ao mundo cristão (Rosselló et alii, 2016). Neste conjunto verifica-se a quase exclusividade da cerâmica comum, tendo sido identificado apenas um fragmento vidrado, informe, cujas características da pasta e do próprio vidrado sugerem horizontes cronológicos emirais. Prevalecem os fabricos a torno, embora se afiram algumas produções manuais/ torno lento. Entre as peças decoradas é de salientar a presença de pintura a branco, negro ou vermelho (Figura 3). Refira-se um fragmento que associa cordão digitado com pintura branca, numa solução decorativa de síntese, conjugando elementos de cariz islâmico com elementos decorativos comuns ao mundo cristão (Rosselló et alii, 2016, p. 59). 
Destaca-se, também, o candil proveniente de Pedrantil (Croca, Penafiel) (Barroca e Santos, 2005), cujas características apontam para cronologia califal. Tratando-se de uma peça isolada e sem contexto arqueológico conhecido, poderá remeter para os contactos comerciais e civilizacionais entre estas populações de fronteira.

Por último, no Castelo de Aguiar de Sousa, o célebre hisn Aquilar sobre o Douro, conquistado por Almançor, cuja tipologia se afasta dos castelos roqueiros cristãos (Silva, 2008), a par das cerâmicas de adscrição cristã, encontramos alguns exemplares que podem remeter para o mundo islâmico, nomeadamente uma peça de pasta clara e moldura no colo (Fonseca, 2014, p. 51, fig. 145).

\subsection{Território a sul do Douro}

A sul do Douro a escassez de dados arqueológicos é semelhante à encontrada a norte, pois, salvo alguns casos, como Coimbra, é muito pouca a informação disponível. As fontes da época são parcas em informação, não existe investigação arqueológica dedicada a estas problemáticas e são raros os estudos centrados no intervalo cronológico relativo às realidades históricas aqui analisadas (Figura 1 e Figura 2).

Assim, no distrito de Aveiro, no Castelo de Santa Maria da Feira foi identificado um conjunto de cerâmica comum, alguma ostentando pintura a branco ou a vermelho, e ainda um bico de candil (Figura 3), datável de finais do século IX ou primeira metade do $\mathrm{X}$, convivendo com cerâmica caracteristicamente cristã, nomeadamente panelas de pastas cinzentas, cozeduras redutoras e asas puncionadas (Teixeira e Fonseca, 2002/2003).

Verificamos realidade idêntica no Castro de Valinhas/Castelo de Arouca, de onde é proveniente um conjunto de materiais com características islâmicas, nomeadamente alguns fragmentos com pintura e outros com vidrados verdes e verde-melados sobre pintura a manganés (Silva e Ribeiro, 2015, p. 316; Silva e Ribeiro, 2014; Silva. 2011, p. 8), a par de outros de cariz cristão.

Em Viseu, cidade que se rendeu por pacto de capitulação, destaca-se um conjunto de cerâmica com cronologia dos séculos X/XI-XII, de aparentes características islâmicas, proveniente do Pátio do Museu Grão Vasco (Rodrigues, 2014). Trata-se de cerâmica de fabrico a torno rápido e cozedura oxidante. A nível decorativo temos os púcaros de colo alto e cilíndrico com caneluras, a pintura a branco e a aplicação de engobe vermelho ou cinzento sobre superfícies vermelhas.

Em meio rural, mas ainda dentro do actual distrito de Viseu, são de referir dois povoados fortificados. O Castro de Mogueira/São Martinho de Mouros (Resende), onde, para além de um dedal mitriforme de bronze com paralelos no mundo islâmico, foi recolhida cerâmica decorada com incisões, cordões plásticos e alguns fragmentos com vidrado melado (Santos, 2012, p. 468). Seguindo a mesma dinâmica de convivência entre o mundo cristão e o mundo islâmico, assinalamos o sítio de Nossa Senhora do Barrocal (Sátão), onde foi identificado um conjunto de peças oriundas do mundo islâmico, nomeadamente os vidrados (verde e manganés, melado, melado e manganés e vidrado a verde plúmbeo) e ainda alguns fragmentos de pequena dimensão de peças pintadas a negro e a branco (Tente et alii, 2018, p. 278). Segundo os autores, estes materiais “( ...) revelam, sem sombra para dúvidas, ligações entre as populações da região viseense com o Sul islamizado. As mesmas podem ainda traduzir materialmente a capacidade de aquisição de peças em mercados onde produtos fabricados no mundo islâmico eram vendidos" (Tente et alii, 2018, p. 279).

No Castelo de Trancoso, sobretudo em torno da Torre de Menagem, foi identificado um importante conjunto de peças filiadas em produções islâmicas, nomeadamente cerâmica pintada a branco e vidrados melados com ou sem traços de manganés (Figura 3 ). Associado a estes materiais, encontra-se, igualmente, um vasto acervo cerâmico de cariz cristão (Ferreira et alii, 2012, p. 18). Neste conjunto, datável entre os séculos VIII e o século XII, predominam os fabricos manuais ou a torno lento e a torno incerto, maioritariamente de cozedura oxidante. Os tratamentos de superfície vão do simples alisamento ao brunido em espatulado, podendo apresentar motivos incisos, cordões plásticos, caneluras e ainda traços pintados a branco (Ferreira et alii, 2012, p. 18).

Na cidade da Guarda, surge um conjunto de cerâmicas, cujos elementos decorativos, tecnológicos e morfológicos apontam para os séculos X-XI. Pontuam panelas de bordos extrovertidos e colos estreitos, cântaros de asas de fita decoradas, com pastas grosseiras de cor acastanhada, creme e alaranjadas. Entre estas, foi identificada uma asa de pasta creme-alaranjada, decorada com traços de engobe branco, que permite especular sobre a presença islâmica na Guarda (Osório, 2004, p. 10). 
Por fim, assinalamos um conjunto de pequenos aglomerados, predominantemente fortificados, situados na região do Alto Mondego (Tente, 2010). Destes povoados, salientamos Soida (Guarda e Celorico da Beira), S. Gens (Celorico da Beira), Castro de Santiago (Fornos de Algodres), Penedo dos Mouros (Gouveia) e Monte Aljão (Gouveia). Na Soida, cujo topónimo de origem muçulmana remete para um local elevado, foi identificada cerâmica medieval maioritariamente oxidante: pastas laranjas, avermelhadas, castanhas-avermelhadas e rosadas, com cronologia entre o século IX e o X. S. Gens apresenta um conjunto cerâmico com algumas peças que remetem para o mundo mais meridional, como, por exemplo, o jarro/púcaro de colo canelado (Souza, 2013, p. 75, fig. 23). No Monte Aljão surge cerâmica com pintura branca, nomeadamente um fragmento de gargalo com arranque de asa, fabrico a torno rápido e cozedura oxidante (Tente, 2010, p. 73 e 109, fig. IV.1.33, n.os 4 e 20). A ocupação medieval do Castro de Santiago (Tente, 2010, p. 330) forneceu uma peça com pintura vermelha na asa, atribuída a época tardo-romana (Tente, 2010, p. 333). Não havendo qualquer outro indício de ocupação romana neste sítio, poderá tratar-se de uma peça islâmica, onde este tipo de produção se encontra difundido a partir do século IX. Por fim, no Penedo dos Mouros, foi identificado um conjunto de peças, entre as quais panelas com cordões plásticos e incisões, jarros com bico "pinçado", alguns fragmentos de cerâmica pintada e uma peça de pasta distinta das restantes e caneluras no colo (Tente, 2010, p. 151 e 198, fig. IV.4.29, n. .66$)$. Os dados recolhidos indicam que alguns destes sítios do Alto Mondego foram abandonados na segunda metade do século $\mathrm{X}$.

No eixo Serra da Estrela/Cova da Beira e seguindo para sul, no distrito de Castelo Branco, temos como referência fundamental a cidade de Laydâniyya (Idanha-a-Velha). Após a conquista islâmica esta cidade terá mantido o seu papel político-administrativo.É identificada nas fontes durante o emirato como uma kura, com, pelo menos, quatro distritos ou iqlim, podendo intuir-se que os seus termos territoriais terão sofrido poucas alterações, pelo menos até finais do século IX, momento em que Córdova perde a vinculação política com os territórios a norte do Tejo. Não há qualquer referência a esta região durante o califado. Sabemos que à região da Egitânia chegaram diferentes grupos de origem berbere, como os Miknasa e os Mas.muda dos Banu Tayit, e que esta zona se viu envolvida em numerosas revoltas, destacando-se as de Ibn Marwan, muladí emeritense, que convulsionaram todo o território durante um período considerável. São factores que marcaram a região, em cuja população se incluíam, à semelhança de praticamente toda a Marca Inferior, elementos de algumas tribos berberes, muladís e moçárabes.

Relativamente aos dados arqueológicos, foi recolhido em Idanha-a-Velha um significativo conjunto de materiais hispano-muçulmanos (Sánchez Hidalgo et alii, 2018). Trata-se de um variado grupo de cerâmicas, destinadas a diferentes usos, como a preparação de alimentos, armazenamento, iluminação, transporte. A maioria das peças possui decorações comuns no mundo islâmico, isto é, pintura (branca, negra ou vermelha), aplicações plásticas, incisa e vidrada, por vezes combinadas. Em síntese, o conjunto cerâmico revela características habituais no mundo islâmico, concretamente entre os séculos $\mathrm{X}$ e XI (Sánchez Hidalgo et alii, 2018, p. 744).

Um pouco mais a norte, integrando o vasto espaço do agora território da kura Laydâniyya, encontra-se a Capela de São Pedro da Capinha (Fundão), onde foram exumados compartimentos habitacionais e um silo, sendo proveniente deste contexto um conjunto de material cerâmico datado de período emiral (Santos e Albuquerque, 2015). Trata-se exclusivamente de cerâmica comum de reduzida variedade formal, destacando-se os grandes contentores que se dividem em dois grupos coexistentes: aqueles que podemos considerar como herdeiros dos dolia, possuindo bordo introvertido praticamente indiferenciado da pança, e as talhas ou grandes potes, de bordo moldurado, por vezes ainda ligeiramente introvertido. Os fabricos são maioritariamente a torno lento, predominando as cozeduras oxidantes. No que respeita à decoração, as caneluras constituem a principal técnica decorativa relativamente à cerâmica de menores dimensões, sendo a decoração incisa, nomeadamente a pente, impressa e aplicada, exclusiva dos grandes contentores, alguns dos quais se apresentam profusamente decorados, por vezes conjugando diferentes técnicas (Figura 3). Pode tratar-se de um conjunto cerâmico de transição entre o mundo visigótico e o emiral, onde se identificam as influências e perdurações típicas do reportório formal romano-visigótico convivendo com peças claramente inovadoras (Santos e Albuquerque, 2015, p. 921).

A norte de Laydâniyya, no Castelo de Belmonte, 
foram reconhecidas cinco fases de ocupação, correspondendo a primeira fase a um momento anterior ao actual edifício do século XIII. Deste período mais antigo foram descobertos restos de estruturas habitacionais, quatro silos e alguns materiais cerâmicos, entre os quais destacamos uma bilha decorada com caneluras na parte superior do bojo e pintura a branco, cuja cronologia foi atribuída aos séculos XII/XIII (Marques, 2000, p. 266 e fig. 17).

$\mathrm{Na}$ Casa da Torre (Caria, Belmonte), foi recolhido abundante espólio, salientando-se um conjunto de cerâmica medieval com características possivelmente islâmicas, como alguns melados com ou sem traços de manganés e o fragmento de um possível jarro, de pasta creme, bem depurada, com esmalte de cor verde (Robalo, 2008, p. 194). Estes materiais coexistem com outros que podemos adscrever ao mundo cristão, nomeadamente recipientes com asas puncionadas. A cronologia indicada situa-se entre o século XII e o XIII, contudo, alguns paralelos apontados podem recuar a cronologia de algumas destas peças ao século XI.

Em Castelo Novo (Fundão) foi recolhido um conjunto significativo de materiais cerâmicos enquadráveis nos séculos XIII e XIV, referindo-se a existência de exemplares vidrados de cor verde, alguns dos quais com decoração estampilhada. Destaca-se um fragmento de parede com arranque de asa que mostra pequeno botão, compatível com produções islâmicas datáveis dos séculos XII/XIII (Silvério e Barros, 2005, p. 59).

Do Castelo de Penamacor, cujo topónimo parece ter fossilizado o nome de Ibn Nakur, um dos rebeldes da fitna de finais do século IX (Catarino e Santos, 2012: 11), é proveniente o fragmento de uma taça decorada a corda seca total, com motivo do cordão da felicidade, ou da eternidade, tema que embora nos remeta para uma filiação islâmica dos séculos XII/ XIII, poderá ser, segundo os autores, "compatível com os modelos mudéjares” (Silvério et alii, 2004, p. 488 , fig. $16, \mathrm{n}^{\circ} 39$ ).

A sul de Laydâniyya, entre o rio Zêzere e a Ribeira da Isna, situa-se o enclave do hisn da Sertã, onde foram identificadas várias fases de ocupação (Batata, 1998; Batata 200o, p. 435-437), salientando-se uma fundição de ferro e cerâmica com cronologias do século X/XI de características islâmicas. Trata-se de cerâmica comum, de pastas e superfícies castanhas e avermelhadas, algumas decoradas com motivos pintados a branco, nas tradicionais formas de pane- las de bordo triangular e púcaros de colo canelado (Batata, 2000, Est. IV).

No Castro de S. Miguel da Amêndoa (Vila de Rei/ Mação), identificaram-se estruturas habitacionais, às quais se encontrava associado um conjunto de materiais cerâmicos, cujas características podem remeter para o período islâmico, embora na época tenham sido datadas do século II a.C. (Bubner e Bubner, 1993, p. 37-40). Trata-se de peças de cor alaranjada, fabrico a torno, normalmente sem decoração, embora, por vezes, apresentem caneluras, incisões e cordões plásticos (Figura 3). Estas peças aproximam-se formalmente, entre outros, de exemplares de Coimbra e Santa Olaia (Montemor-o-Velho), aqui em contextos dos séculos X/XII.

Por fim, da cidade de Castelo Branco, temos notícia de algumas peças de cariz islâmico, nomeadamente um bico de candil, cuja forma larga e curta denuncia a sua cronologia tardia, apontando para meados do seculo XII (Boavida, 2013, p. 962 e 965, fig. 4). Do castelo são provenientes materiais medievais, entre os quais alguns fragmentos de cerâmica com pintura branca (Boavida, 2015, p. 910).

Na região do Baixo Mondego, a cidade de Coimbra, uma das principais cidades da Marca Inferior, cujas fontes árabes indicam que capitulou a Abd al-Aziz em 714/715, terá, possivelmente, correspondido a uma cidade-território, centro de um 'amal não militarizado. Agora designada como Madinat Qulumriyya, terá sido o centro de um vasto território herdado da anterior diocese (Catarino, 2008, p. 135). Embora a população fosse maioritariamente moçárabe, também se instalaram no território de Coimbra grupos de berberes, como os Masmuda e os Sadfura, sobre os quais nos informam as mesmas fontes (Catarino, 2008, p. 137). Desde a capitulação até 1064, altura em que cai definitivamente em administração do poder cristão, a história do governo das terras de Coimbra vai ser pontuada, como em todo o território de fronteira, por uma alternância de poderes entre cristãos e muçulmanos, reflectida na cultura material que parece evidenciar coexistência de cerâmicas do "mundo cristão" e do "mundo islâmico". São conhecidos importantes vestígios da ocupação da cidade em período islâmico no Museu Machado de Castro e zonas adjacentes (Silva 2014; Silva 2015), e nos espaços da Universidade de Coimbra, particularmente no Pátio das Escolas da Universidade de Coimbra, no Colégio da Trindade e no Largo D. Dinis (Catarino et alii, 2009). A cerâmica recolhida 
atesta uma ocupação centrada na época califal / taifas (séculos X/XI) prolongando-se algumas formas e decorações até ao século XII (Figura 3). Sendo notório o predomínio da cerâmica comum de cozedura oxidante, podem ostentar pintura a negro, vermelho ou branco. A presença de cerâmica vidrada é assinalável, relacionando-se com importações de diversas regiões do al-Andalus. Estão representados os melados, os melados com traços de manganés, o verde e manganés, a corda seca parcial e a corda seca total, sendo ainda de referir a presença de dois fragmentos de louça dourada (Catarino et alii, 2009, p. 353).

Em Conimbriga (Condeixa), antiga diocese visigótica, além da recolha de moedas e dos enterramentos muçulmanos, há também a referir a cerâmica, nomeadamente, entre outras, as cerâmicas pintadas a branco e os púcaros de colo canelado (De Man et alii, 2014), indício da presença islâmica nessa antiga cidade.

Ainda em Condeixa, no Paço da Ega (Condeixa) foi exumado um conjunto cerâmico de características islâmicas, que reportam a horizontes cronológicos dos séculos X-XI. Constitui-se como um conjunto muito homogéneo, de pouca variedade formal e predomínio das formas fechadas. Relativamente aos modelos decorativos, denota-se a utilização da pintura a branco como técnica dominante (Revez, 2012, p. 52). Em Montemor-o-Velho, o período muçulmano está comprovado pelos vestígios arqueológicos, nomeadamente cerâmica com pintura branca, um capitel e estuques trabalhados (Barroca, 2005, p. 115), com paralelos califais/taifas, lápides moçárabes e uma inscrição árabe (Penajoia, 2014, p. 246-247).

O outeiro de Santa Olaia (Figueira da Foz) forneceu um conjunto de cerâmicas de cariz cristão coexistentes com cerâmicas de pastas oxidantes, com superfícies polidas, engobadas e pintadas em bandas a branco (Figura 3), possivelmente importadas do Sul do Garb al-Andalus, que se enquadram nas épocas emiral/califal e reinos de taifas. É ainda de referir a presença de peças que conjugam particularidades de filiação cristã e islâmica (Nazaré, 2013, p. 86-87).

Já no distrito de Leiria, há a referir um conjunto de candis e pesos de tear, ainda por publicar, alguns com indícios de vidrado (Figura 3), datável dos séculos $\mathrm{X} / \mathrm{XII}$, provenientes de Ansião (Pombal) ${ }^{12}$. Trata-se de peças sem contexto arqueológico, mas importantes enquanto reveladoras dos contactos existentes.

12. Colecção Padre José Eduardo Coutinho.
No Castelo de Leiria foram realizados trabalhos arqueológicos na Torre de Menagem, daí resultando alguns testemunhos eventualmente islâmicos, nomeadamente escassos fragmentos de cântaros e púcaros, destacando-se os motivos decorativos em caneluras e os pintados a branco, com cronologia de "inícios do Califado, ou mesmo ainda do Emiral" (séculos IX/X) (Lopes, 2001, p. 33). Nos estratos seguintes assinalou-se igualmente a presença de cerâmica com formas e decorações próprias dos modelos que acompanham a reconquista cristã. $\mathrm{Na}$ envolvente do castelo, nomeadamente no interior da primeira linha de muralha, foram exumados alguns fragmentos cerâmicos possivelmente atribuíveis a produção islâmica. O conjunto merece alguma cautela, pois se alguns materiais poderão ser classificados de época emiral/califal, outros apenas poderão ser genericamente considerados islâmicos. Após 1135 o Castelo esteve efectivamente ocupado por tropas muçulmanas em dois períodos muito próximos no tempo, até à sua conquista pelos cristãos por volta de 1140/1142. Os vestígios referidos podem relacionar-se com estas ocupações (Carvalho e Inácio, 2013, p. 162).

O sítio Quinta da Granja I (Maiorga, Alcobaça) forneceu recipientes de cariz utilitário sobretudo para cozinhar e também para transportar/servir alimentos à mesa e armazenagem. A maioria dos fragmentos cerâmicos de cariz islâmico pertence a formas fechadas, principalmente panelas ou potes, jarros, jarrinhas, cântaros e talhas (Figura 3). Globalmente, o espólio pode integrar-se na Alta Idade Média, entre os séculos VII e IX, parecendo reunir influências visigóticas e emirais (Gonzalez, 2013, p. 916).

Já no distrito de Santarém, no limite geográfico aqui em estudo, há a referir Tomar e Torres Novas. Tomar possui evidências de ocupação nos séculos IX-X e no forum de Sellium/Tomar, foi encontrada uma moeda coetânea da conquista islâmica. Relativamente às cerâmicas, não foram ainda recuperados exemplares correlacionáveis claramente com produções islâmicas.

Em Torres Novas foram identificadas estruturas habitacionais, silos e lixeiras de época islâmica, das quais são provenientes materiais cerâmicos que podemos colocar em dois momentos cronológicos: um conjunto, tipológica e cronologicamente homogéneo, sem grande diversidade formal, que poderá ser enquadrado nos séculos $\mathrm{X} / \mathrm{XI}$; e outro conjunto com cronologia dos séculos XII/XIII. É de referir a 
presença de um cantil de pasta bege e decoração pintada a vermelho, de produção exógena à região (Lopes, 2007, p. 322).

\section{A SÍNTESE POSSÍVEL}

Neste trabalho procurámos sistematizar os objectos e conjuntos cerâmicos identificados no território hoje português da Marca Inferior, com cronologia entre os séculos VIII e XII, cujas características, de forma mais ou menos evidente, se podem relacionar com as produções cerâmicas islâmicas do Garb al-Andalus, distinguindo-se das comuns e conhecidas naqueles território e cronologia. A realidade observada é ainda bastante difusa em grande parte do território analisado, principalmente na zona mais setentrional. A filiação islâmica das cerâmicas aqui analisadas é evidente nalguns casos e, mais frequentemente, apenas hipotética. A título de exemplo, refira-se a dificuldade na distinção entre cerâmicas alto-medievais visigóticas e emirais; e entre cerâmicas medievais islâmicas e algumas produções tardo medievais cristãs de tradição mudéjar (séculos XIII e XIV). Mais complexa ainda é a interpretação de achados isolados e conjuntos, uma vez que não é fácil relacionar estes materiais com a presença de populações islâmicas ou de cultura islâmica e menos ainda com um domínio islâmico territorial efectivo. Os contactos e as trocas, de natureza diversa, entre cristãos e muçulmanos, neste território, ocorreram decerto durante todo o período em que aqui conviveram, negociaram, viajaram e se confrontaram.

A norte do Douro, embora se identifiquem cerâmicas de cozedura redutora, mais presentes nas áreas de "fronteira" do al-Andalus, verifica-se, igualmente, em pequena escala, o aparecimento de novidades formais e ornamentais. Aliando a diminuta presença muçulmana nestas terras a norte do Douro à ausência de estudos vocacionados para os séculos VIII/IX, bem como ao débil conhecimento dos materiais que caracterizam o período islâmico inicial, deparamo-nos com uma escassez de informação arqueológica superior àquela que as fontes indicam. Deste modo, além de ser imprescindível incrementar as intervenções e os estudos, tendo como objectivo reconhecer a presença islâmica e de materiais islâmicos nestas regiões mais nortenhas da Marca Inferior, é também fundamental a revisão de algumas cerâmicas atribuídas genericamente à Antiguidade Tardia.
A sul do Douro, o "inventário" dos sítios com indícios de presença islâmica ou de contactos com o mundo islâmico denota, tal como acontece para a região mais a norte, as lacunas da investigação, sugerindo uma certa relutância em aceitar a influência islâmica para as áreas setentrionais da "fronteira". Continuam a ignorar-se as evidências toponímicas, que, embora impere a onomástica cristã arabizada, indica a existência de grupos árabes-berberes. Regista-se, igualmente, o desconhecimento do povoamento rural, nomeadamente dos sítios rurais de transição (séc. VII/VIII e séc. VIII/IX). Num território de população predominantemente cristã (pese embora os grupos de berberes que aqui se estabeleceram), em que a conquista se fez sobretudo por pactos de capitulação, e onde os sucessivos movimentos de conquistas e reconquistas impediram uma ocupação islâmica continuada, torna-se muito difícil distinguir no terreno os vestígios que nos deixaram as populações que o habitaram entre os séculos VIII e XII. De qualquer forma, deve referir-se alguma convergência na distribuição dos vestígios arqueológicos e nas referências documentais, essencialmente na fase califal/taifa (Figura 2). Se bem que beneficiando de estudos importantes no que toca à componente moçárabe da população e de abordagens com recurso à toponímia, a caracterização do processo de islamização nestes territórios, particularmente no que concerne aos abandonos e continuidades entre os períodos visigótico e emiral, carece de aprofundamento.

\section{BIBLIOGRAFIA}

BATATA, Carlos (1998) - Carta arqueológica do concelho da Sertã. Sertã: Câmara Municipal da Sertã.

BATATA, Carlos (200o) - Presença árabe no Castelo da Sertã (Centro de Portugal). In Actas do 3. . Congresso de Arqueologia Peninsular, vol. VII - Arqueologia da Idade Média da península Ibérica. Porto: ADECAP, pp. 435-437.

BARROCA, Mário Jorge (2005) - O castelo de Montemor-o-Velho nos séculos X a XIII. In Muçulmanos e Cristãos entre o Tejo e o Douro (Sécs. VIII a XIII). Palmela: Câmara Municipal de Palmela/Faculdade de Letras da Universidade do Porto. Palmela, pp. 111-126.

BARROCA, Mário Jorge (2008-2009) - De Miranda do Douro ao Sabugal - Arquitectura Militar e Testemunhos Arqueológicos Medievais num Espaço de Fronteira. Portugália. Porto. Nova Série, XXIX-XXX, pp. 193-252.

BARROCA, Mário Jorge (2016) - Muçulmanos e Cristãos no Douro português (séc. VIII-XI). In Atas das $4 \cdot{ }^{a s}$ Confe- 
rências do Museu de Lamego. Porto: CITCEM/FLUP. Disponível em: www.museudelamego.pt.

BARROCA, Mário Jorge; SANTOS, Maria José Ferreira dos (2006) - O candil califal de Pedrantil (Croca, Penafiel). In Al-Ândalus espaço de mudança. Balanço de 25 anos de história e arqueologia medievais, Seminário de Homenagem a Juan Zozaya Stabel-Hansen (Mértola 2005). Mértola: Campo Arqueológico de Mértola, pp. 310-317.

BOAVIDA, Carlos (2013) - Castelo de Castelo Branco achados fortuitos nas colecções do Museu Francisco Tavares Proença Júnior. In Arqueologia em Portugal 150 anos. Lisboa: Associação dos Arqueólogos Portugueses, pp. 961-967.

BOAVIDA, Carlos (2015) - Medieval pottery from the Castle of Castelo Branco. In X Congresso Internacional a Cerâmica Medieval no Mediterrâneo (Silves/Mértola, 2012). Silves: Câmara Municipal de Silves / Campo Arqueológico de Mértola, pp. 906-911.

BROCHADO, Cláudio Roberto Laranjeira (2004) - Povoamento tardo-romano e altomedieval na bacia terminal do Rio Lima (séculos IV-XI). Dissertação de Mestrado em Arqueologia apresentada à Faculdade de Letras da Universidade do Porto. Disponível em: https://hdl.handle.net/ $10216 / 15264$.

BUBNER, Maria Amélia Horta Pereira; BUBNER, Thomas (1993) - Castro de São Miguel de Amêndoa. Relatório dos trabalhos 88-89. Arquivo da Arqueologia Portuguesa, DGPC, processo $\mathrm{S}-852$ (documento policopiado).

BUBNER, Maria Amélia Horta Pereira; BUBNER, Thomas (1993a) - O Castro de S. Miguel de Amêndoa (Mação) - Noticia Preliminar das escavações efectuadas. Arquivo da Arqueologia Portuguesa, DGPC, processo S-852 (documento policopiado).

CARVALHO, Vânia; INÁCIO, Isabel (2013) - O Projeto de Investigação Arqueológica do Núcleo do Castelo de Leiria: enquadramento, objetivos e resultados. In Arqueologia em Portugal 150 anos. Lisboa: Associação dos Arqueólogos Portugueses, pp. 157-164.

CATARINO, Helena (2008) - A Marca Inferior em Portugal na época de Almansor: hipóteses de trabalho e os exemplos de Viseu e Coimbra. In La Península Ibérica al Filo del Año 10oo. Congreso Internacional Almanzor y su época (Córdoba, 14 a 18 de octubre de 2002). Córdova: Fundación Prasa, pp. 123-146.

CATARINO, Helena; FILIPE, Sónia; SANTOS, Constança (2009) - Coimbra islâmica: uma aproximação aos materiais cerâmicos. In Actas do 6ํㅡㄹ Encontro de Arqueologia do Algarve. O Gharb no al-Andalus; síntese e perspectivas de estudo. Homenagem a José Luís de Matos (Silves, 2008) (Xelb, 9). Silves: Museu Municipal de Arqueologia/Câmara Municipal de Silves, pp. 333-376.

CATARINO, Helena; SANTOS, Constança dos (2012) - A cerâmica Islâmica da Marca Inferior em território português. Arqueologia Medieval. Porto. 12, pp.7-14.
DE MAN, Adriaan; CORREIA, Virgílio H.; LOVEGROVE, Sofia; ANDRADE, Francisco (2014) - Cerâmica medieval de Conímbriga. In DE MAN, Adriaan; TENTE, Catarina, coord. - Estudos de Cerâmica Medieval - o Norte e Centro de Portugal, séculos IX a XII. Lisboa: Instituto de Estudos Medievais/Faculdade de Ciências Sociais e Humanas/Universidade Nova de Lisboa, pp. 57-68.

FONSECA, Jorge Manuel Vieira (2014) - Relatório Final. Estudo para a Definição da área arqueológica da Torre do castelo de Aguiar de Sousa. Arquivo da Arqueologia Portuguesa, DGPC, processo S - 30326 (documento policopiado).

GONZALEZ, Cristina (2013) - Quinta da Granja I (Maiorga, Alcobaça): novos dados sobre o povoamento da Estremadura na Alta Idade Média. In Arqueologia em Portugal 150 anos. Lisboa: Associação dos Arqueólogos Portugueses, pp. 913-921.

LOPES, Gonçalo (2002) - Cerâmicas medievais da Torre de Menagem do Castelo de Leiria. In Torre de Menagem do Castelo de Leiria. Leiria: Câmara Municipal de Leiria, pp. 32-37.

LOPES, Gonçalo (2007) - Um cantil almóada em Torres Novas. Nova Augusta, Revista de Cultura. Torres Novas. 19, pp. 319-330.

MARQUES, António Augusto da Cunha (2000) - Escavações arqueológicas no castelo de Belmonte (1992-1995). In Actas. Beira Interior Historia e Património. Guarda: Câmara Municipal da Guarda, pp. 253-286.

NAZARÉ, M. J. V. (2013) - Cerâmicas medievais de Santa Olaia (Figueira da Foz) depositadas no Museu Municipal Dr. Santos Rocha. Relatório de Estágio 2 Ciclo/ Mestrado em Arqueologia e Território. DHAA / FLUC. Disponível em: http://hdl.handle.net/10316/23836.

OSÓRIO, Marcos (2004) - Novos contributos para o estudo dos Castelos Velhos (Guarda). Praça Velha. Guarda. 15, pp. 5-15.

PENAJOIA, Marco (2014) - Grafitos, inscrições árabes e outras marcas históricas identificadas no castelo de Montemor-o-Velho. Revista de História da Sociedade e da Cultura. Coimbra. 14, pp. 231-252. Disponível em: http://hdl.handle.net/10316.2/39367.

REVEZ, Ana Lima (2012) - Trabalhos arqueológicos no projecto de recuperação do Paço da Ega (2007-2009). Arqueologia Medieval. Porto. 12, pp. 41-57.

ROBALO, Elisabete Martins (2008) - Escavações arqueológicas na Casa da Torre (Caria - Belmonte). Resultados preliminares. In Actas das I Jornadas de Belmonte. Belmonte: Câmara Municipal de Belmonte, pp. 188-215.

RODRIGUES, Patrícia (2014) - Cerâmicas medievais do Pátio do Museu Grão Vasco (Viseu): elementos para uma sistematização da cerâmica pleno medieval do espaço viseense. In DE MAN, Adriaan; TENTE, Catarina, coord. - Estudos de Cerâmica Medieval - o Norte e Centro de Portugal, séculos IX a XII. Lisboa: Instituto de Estudos Medievais/Faculdade 
de Ciências Sociais e Humanas/Universidade Nova de Lisboa, pp. 141-16o.

ROSSELLÓ, Miquel; SANTOS, Constança; CARVALHO, Liliana; SANTOS, Filipe (2016) - Contributo para o conhecimento das ocupações tardo-antiga e alto-medieval do Vale do Sabor. O caso de Cilhades (Felgar, Torre de Moncorvo), à luz do estudo da sua componente cerâmica. Arqueologia Medieval. Porto. 13, pp. 35-63.

SÁNCHEZ HIDALGO, Fernando; SANABRIA MURILLO, Diego; MORÍN DE PABLOS, Jorge; SÁNCHEZ RAMOS, Isabel María (2018) - La cerámica andalusí de Idanha-a-Velha (Portugal). In VIII Encontro de Arqueologia do Sudoeste Peninsular. Encuentro de Arqueología del Suroeste Peninsular (Serpa/Aroche, 2014). Serpa: Câmara Municipal de Serpa, pp. 741-748.

SANTOS, Maria Constança; ALBUQUERQUE, Elisa (2015) - A Capela de São Pedro da Capinha através dos materiais: a cerâmica medieval. In X Congresso Internacional a Cerâmica Medieval no Mediterrâneo (Silves/Mértola, 2012). Silves: Camara Municipal de Silves / Campo Arqueológico de Mértola, pp. 917-923.

SANTOS, Maria João Correia dos (2012) - La arqueologia, lo imaginario y lo real. El santuario rupestre de Mogueira (São Martinho de Mouros, Portugal). Madrider Mitteilungen. Madrid. 53, pp. 455-496.

SILVA, António Manuel (2011) - No tempo dos Mouros. Castelos de Arouca numa terra de fronteira (séculos IX-XI). Arouca: Câmara Municipal de Arouca.

SILVA, António Manuel S. P.; RIBEIRO, Manuela C. S. (2014) - Cerâmicas do período da reconquista no Vale do Arda: Castelo de Arouca e Casal da Malafaia. In DE MAN, Adriaan; TENTE, Catarina, coord. - Estudos de Cerâmica Medieval -o Norte e Centro de Portugal, séculos IX a XII. Lisboa: Instituto de Estudos Medievais/Faculdade de Ciências Sociais e Humanas/Universidade Nova de Lisboa, pp. 161-182.

SILVA, António Manuel S. P.; RIBEIRO, Manuela C. S. (2015) - Cerâmicas medievais (séc.s IX-XII) do Castelo de Arouca (N. Portugal). In X Congresso Internacional a Cerâmica Medieval no Mediterrâneo (Silves/Mértola, 2012). Silves: Camara Municipal de Silves / Campo Arqueológico de Mértola, pp. 310-317.

SILVA, Maria Antónia (2008) - Torre do Castelo de Aguiar de Sousa: resultados preliminares de uma sondagem arqueológica. Oppidum. Lousada. Número especial, pp. 117-130.

SILVA, Ricardo Costeira da (2014) - A cerâmica dos níveis alto-medievais do fórum de Aeminium (MNMC, Coimbra). In DE MAN, Adriaan; TENTE, Catarina, coord. - Estudos de Cerâmica Medieval - o Norte e Centro de Portugal, séculos IX a XII. Lisboa: Instituto de Estudos Medievais / Faculdade de Ciências Sociais e Humanas / Universidade Nova de Lisboa, pp. 79-98.
SILVA, Ricardo Costeira da (2015) - Medieval pottery from the Forum of Aeminium (Coimbra, Portugal): a proposal of chrono-typological evolution. In X Congresso Internacional a Cerâmica Medieval no Mediterrâneo (Silves/Mértola, 2012). Silves: Camara Municipal de Silves / Campo Arqueológico de Mértola, pp. 739-749.

SILVÉRIO, Silvina; BARROS, Luís de; TEIXEIRA, André (2004) - Escavações arqueológicas no castelo de Penamacor/Cimo da Vila: resultados da primeira campanha (2003). Revista Portuguesa de Arqueologia. Lisboa. 7:2, pp. 497-540.

SILVÉRIO, Silvina; BARROS, Luís de (2005) - Arqueologia no Castelo da Aldeia Histórica de Castelo Novo (20022004) Resultados Preliminares. Fundão: Câmara Municipal do Fundão.

SOUZA, Gabriel Manzoni Venturini (2017) - O sítio alto-medieval de S. Gens (Celorico da Beira). Contributo para o estudo da produção cerâmica identificada nas campanhas realizadas 2011-2013. Dissertação de Mestrado apresentada à Faculdade de Ciências Sociais e Humanas da Universidade Nova de Lisboa. Disponível em: http://hdl.handle. net/10362/20270.

TEIXEIRA, Ricardo; FONSECA, Victor (2002/2003) - Relatório Intervenção Arqueológica. Castelo de Santa maria da Feira. 2002/2003. Arquivo da Arqueologia Portuguesa, DGPC, processo S - 6371 (documento policopiado).

TENTE, Catarina (2010) - Arqueologia Medieval Cristã no Alto Mondego. Ocupação e exploração do território nos séculos V a XI. Dissertação de Doutoramento apresentada Faculdade de Ciências Sociais e Humanas da Universidade Nova de Lisboa. Disponível em: https://run.unl.pt/ handle/10362/4804.

TENTE, Catarina; BAPTISTA, Hugo; TERESO, João Pedro; CÉRCIO, Margarida; VELOSO, João Luís; OLIVEIRA, Cláudia; SEABRA, Luís; MEIRA, Catarina; SOUZA, Gabriel de; CORDERO RUIZ, Tomás; REAL, Manuel Luís (2018) - Senhora do Barrocal (Sátão) na viragem do milénio. Primeira abordagem. In Do Império ao reino. Viseu e o território entre os séculos IV a XII. Viseu: Câmara Municipal de Viseu, pp. 195-263.

VIGUERA MOLINS, Maria-Jesus (1998) - En Torno a Riba Coa y Al-Andalus. In O Tratado de Alcanices e a Importância História das Terras de Riba Côa. Actas do Congresso Histórico Luso-Espanhol (1997). Lisboa: Universidade Católica Editora, pp. 131-152. 


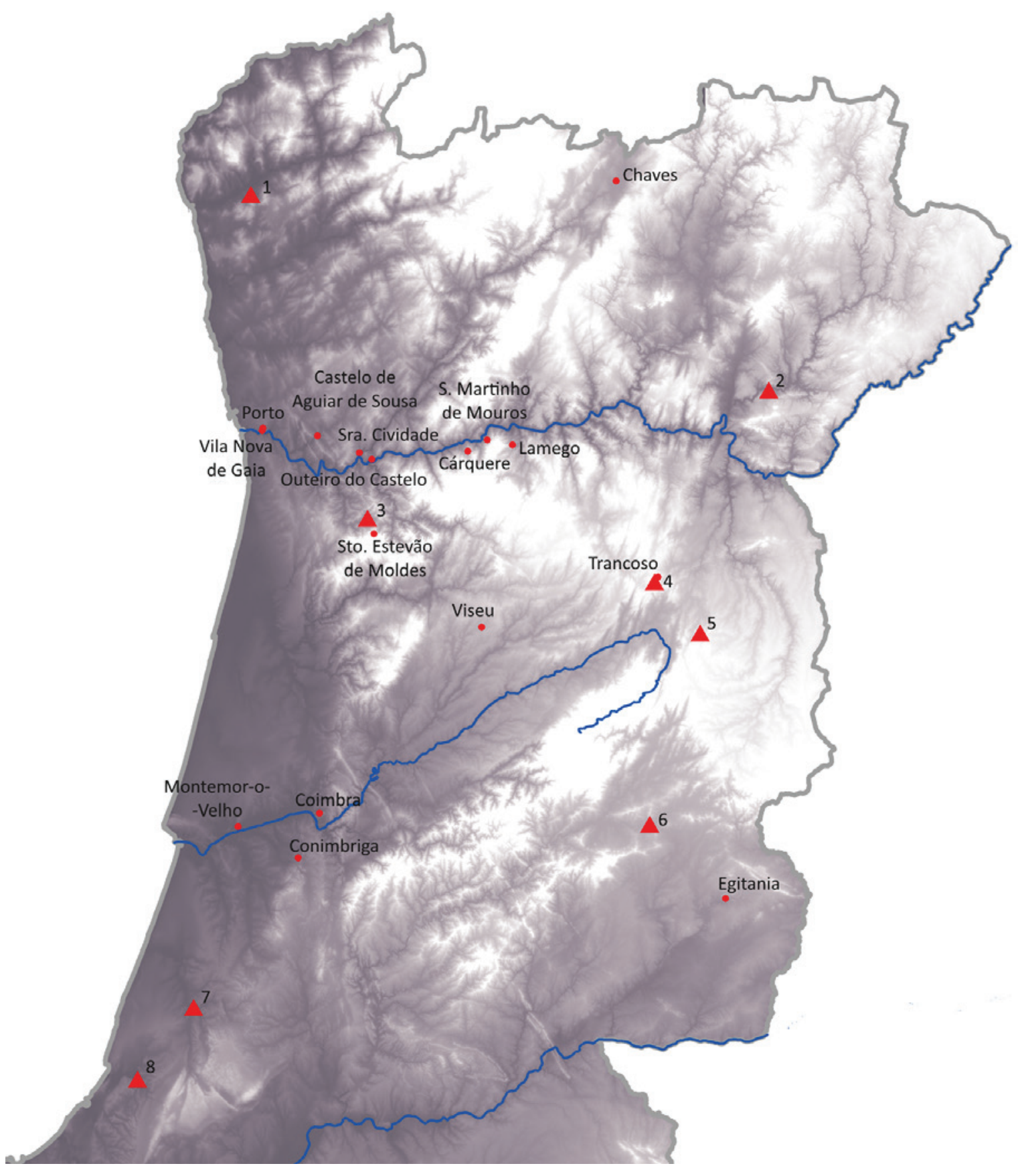

Figura 1 - Distribuição dos sítios arqueológicos com cronologia Emiral, com indicação dos locais referidos na documentação (Barroca, 2008-2009 e 2016; Viguera Molins, 1998).

Sítios que forneceram conjuntos cerâmicos: 1: Quinta do Paço Velho (Ponte de Lima); 2: Cilhades (Torre de Moncorvo); 3: Castro do Monte Valinhas (Arouca); 4: Trancoso (Trancoso); 5: Torre do Codesseiro (Guarda); 6: São Pedro de Capinha (Fundão); 7: Castelo de Leiria (Leiria); 8: Quinta da Granja (Alcobaça). 


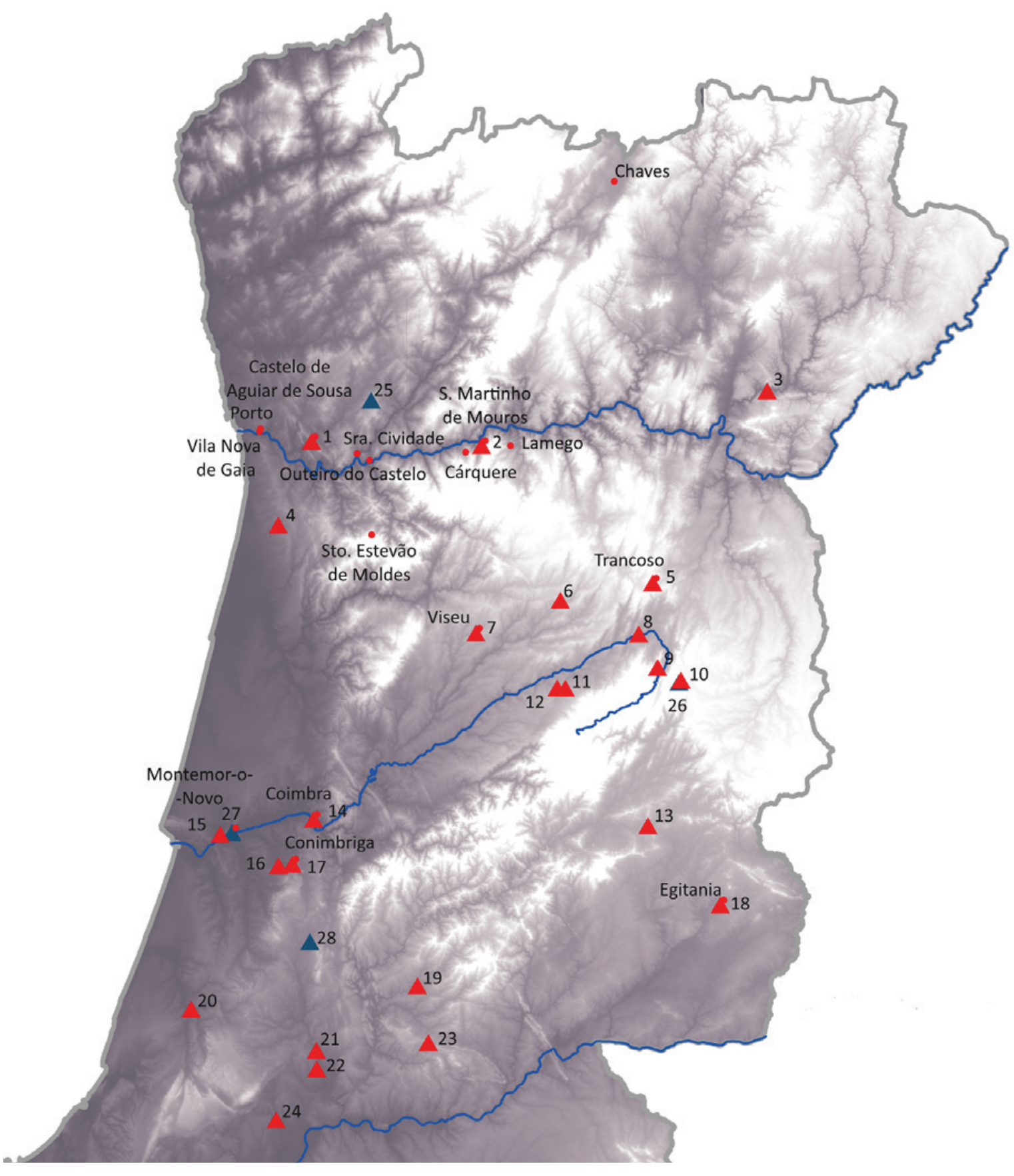

Figura 2 - Distribuição dos sítios arqueológicos com cronologia Califal-Taifas, com indicação dos locais referidos na documentação (Barroca, 2008-2009 e 2016; Viguera Molins, 1998).

Sítios que forneceram conjuntos cerâmicos: 1: Castelo de Aguiar de Sousa (Paredes); 2: Castro da Mogueira/São Martinho de Mouros (Resende); 3: Cilhades (Torre de Moncorvo); 4: Castelo da Feira (Santa Maria da Feira); 5: Trancoso (Trancoso); 6: Senhora do Barrocal II (Satão); 7: Viseu (Viseu); 8: São Gens (Celorico da Beira); 9: Soida (Guarda); 10: Castelos Velhos (Guarda); 11: Penedo dos Mouros (Gouveia); 12: Monte Aljão (Gouveia); 13: São Pedro da Capinha (Fundão); 14: Coimbra (Coimbra); 15: Santa Olaia (Figueira da Foz); 16: Paço da Ega (Condeixa-a-Nova); 17: Conimbriga (Condeixa-a-Nova); 18: Egitania/Idanha-a-Velha (Idanha-a-Nova); 19: Sertã (Sertã); 20: Castelo de Leiria (Leiria); 21: Gruta do Caldeirão (Tomar); 22: Tomar (Tomar); 23: Castro de São Miguel da Amêndoa (Vila de Rei/Mação); 24: Torres Novas (Torres Novas).

Achados isolados: 25: Croca (Penafiel); 26; Guarda (Guarda); 27: Montemor-o-Velho (Montemor-o-Velho); 28: Ansião (Ansião). 


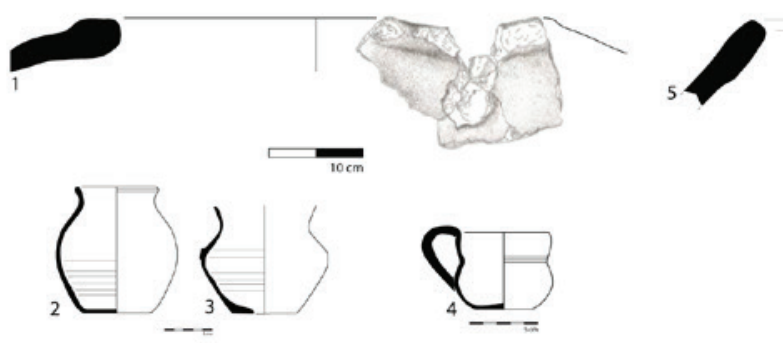

Quinta da Granja (Alcobaça)
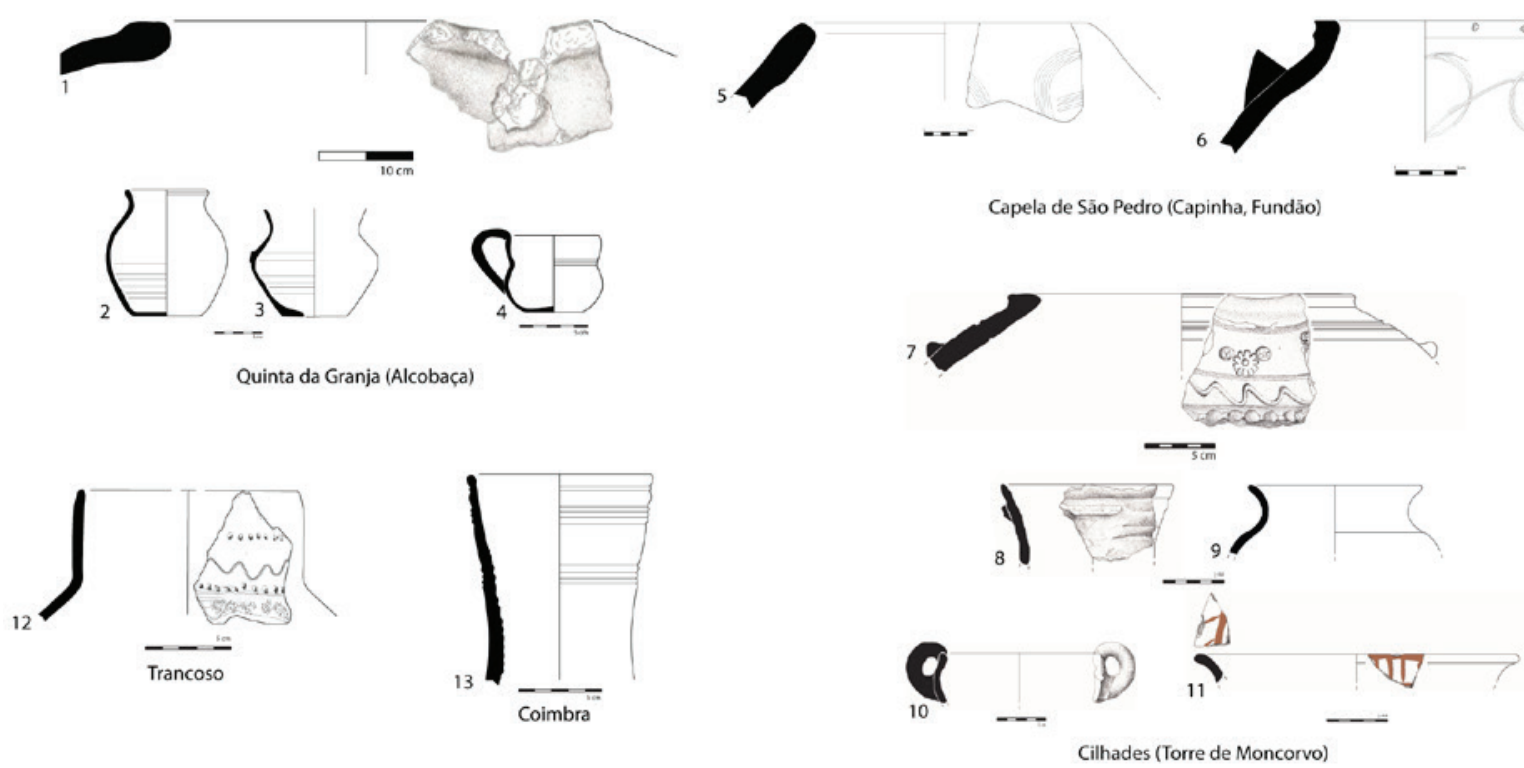

Período Califal-Taifas (século X/XI)

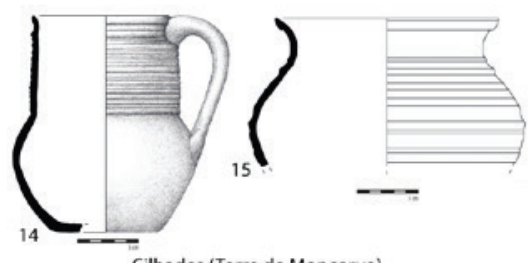

Cilhades (Torre de Moncorvo)
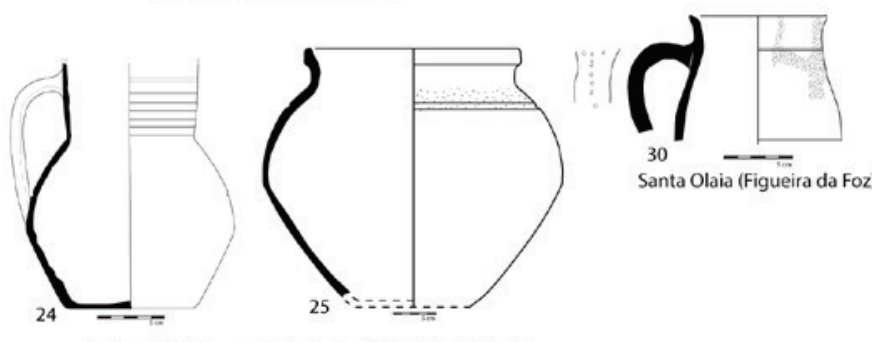

$--$
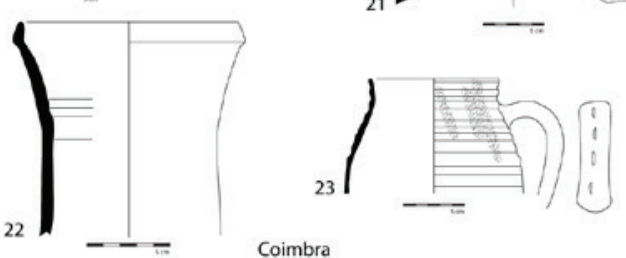

Castro de S. Migues da Amêndoa (Vila de Rei / Maçăo)

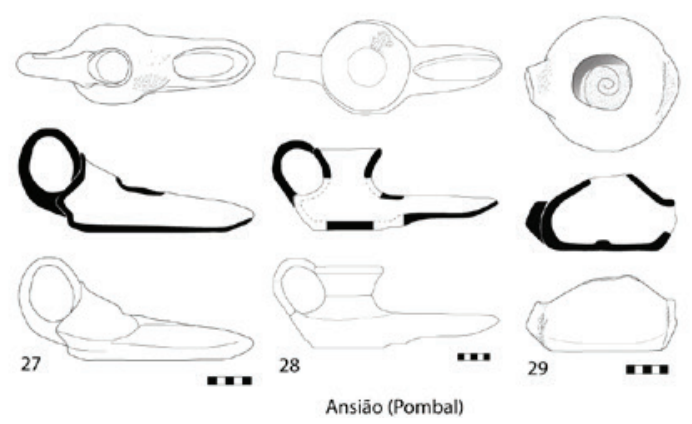

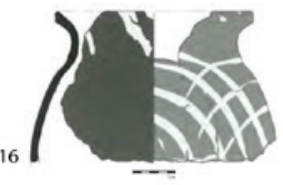

Santa Maria da Feira

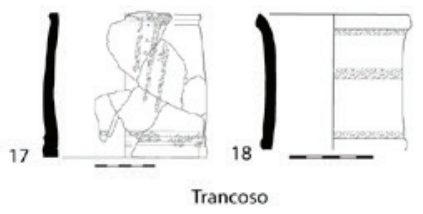

Figura 3 - Cerâmicas islâmicas do Garb setentrional “português”. (1-4) Quinta da Granja, Maiorga, Alcobaça (Gonzalez, 2013); (5 e 6) Capela de São Pedro, Capinha, Fundão (Santos e Albuquerque, 2015); ( 7 a 11, 14 e 15) Cilhades, Felgar, Torre de Moncorvo (Rosselló et alii, 2016); (12, 17 e 18) Castelo de Trancoso, Trancoso (Ferreira et alii, 2012); (13, 19 e 22) Pátio das Escolas da Universidade de Coimbra, Coimbra (Catarino et alii, 2009); (16) Castelo de Santa Maria da Feira, Santa Maria da Feira (Teixeira e Fonseca, 2002/2003); (20, 21 e 23) Beco das Condeixeiras, Coimbra (Silva, 2014); (24 e 25) Castro de S. Miguel da Amêndoa, Vila de Rei / Mação (Bubner e Bubner, 1993 e 1993a); (27-29) Ansião, Pombal (colecção Padre José Eduardo Coutinho); (3o) Santa Olaia, Figueira da Foz (Nazaré, 2013). 


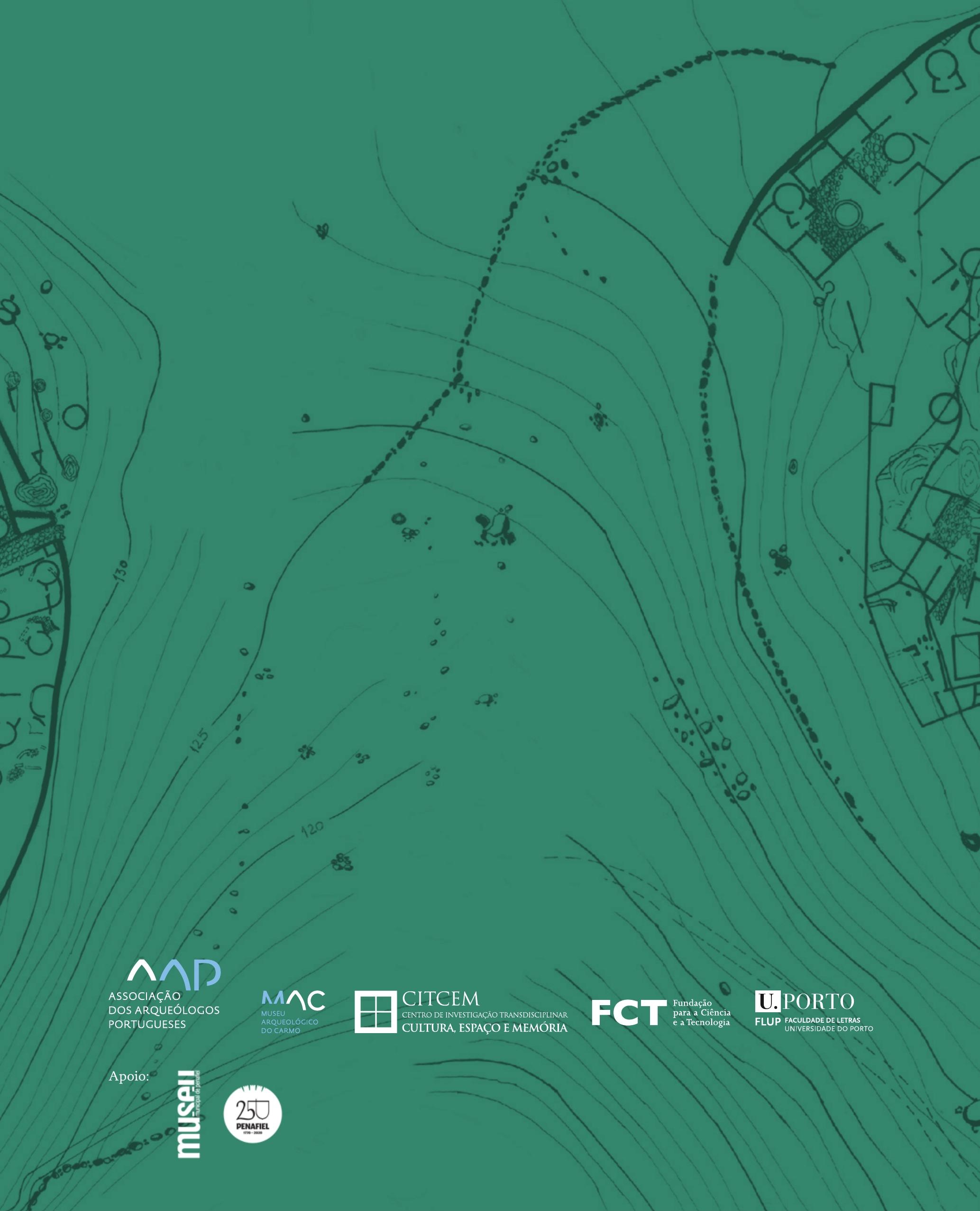

